\title{
Human neuronal signaling and communication assays to assess functional neurotoxicity
}

\author{
Dominik Loser ${ }^{1,2,4}\left(\mathbb{D} \cdot\right.$ Jasmin Schaefer ${ }^{1,2} \cdot$ Timm Danker $^{2} \cdot$ Clemens Möller $^{4} \cdot$ Markus Brüll $^{3} \cdot$ Ilinca Suciu $^{3}$. \\ Anna-Katharina Ückert ${ }^{3}$. Stefanie Klima ${ }^{3}$ - Marcel Leist ${ }^{3}$ - Udo Kraushaar ${ }^{1}$
}

Received: 15 September 2020 / Accepted: 16 November 2020 / Published online: 2 December 2020

(C) The Author(s) 2020

\begin{abstract}
Prediction of drug toxicity on the human nervous system still relies mainly on animal experiments. Here, we developed an alternative system allowing assessment of complex signaling in both individual human neurons and on the network level. The LUHMES cultures used for our approach can be cultured in 384-well plates with high reproducibility. We established here high-throughput quantification of free intracellular $\mathrm{Ca}^{2+}$ concentrations $\left[\mathrm{Ca}^{2+}\right]_{\mathrm{i}}$ as broadly applicable surrogate of neuronal activity and verified the main processes by patch clamp recordings. Initially, we characterized the expression pattern of many neuronal signaling components and selected the purinergic receptors to demonstrate the applicability of the $\left[\mathrm{Ca}^{2+}\right]_{\mathrm{i}}$ signals for quantitative characterization of agonist and antagonist responses on classical ionotropic neurotransmitter receptors. This included receptor sub-typing and the characterization of the anti-parasitic drug suramin as modulator of the cellular response to ATP. To exemplify potential studies on ion channels, we characterized voltage-gated sodium channels and their inhibition by tetrodotoxin, saxitoxin and lidocaine, as well as their opening by the plant alkaloid veratridine and the food-relevant marine biotoxin ciguatoxin. Even broader applicability of $\left[\mathrm{Ca}^{2+}\right]_{i}$ quantification as an end point was demonstrated by measurements of dopamine transporter activity based on the membrane potential-changing activity of this neurotransmitter carrier. The substrates dopamine or amphetamine triggered $\left[\mathrm{Ca}^{2+}\right]_{\mathrm{i}}$ oscillations that were synchronized over the entire culture dish. We identified compounds that modified these oscillations by interfering with various ion channels. Thus, this new test system allows multiple types of neuronal signaling, within and between cells, to be assessed, quantified and characterized for their potential disturbance.
\end{abstract}

Keywords Channel toxins $\cdot$ Neuronal network $\cdot$ Purinoceptor $\cdot$ Dopamine transporter $\cdot$ Network oscillations

\begin{tabular}{|c|c|c|c|}
\hline & & Abbrevia & ons \\
\hline & & AMP & Amphetamine \\
\hline & rcel Leict and UUdo Krauchaar contributed eaually & ATP & Adenosine 5' -triphosphate \\
\hline & rcel Leist and Udo Kraushaar contributed equally. & cAMP & N6,2'-0-dibutyryl 3',5'-cyclic adenosine \\
\hline & $\begin{array}{l}\text { ctronic supplementary material The online version of this } \\
\text { cle (https://doi.org/10.1007/s00204-020-02956-3) contains } \\
\text { plementary material, which is available to authorized users. }\end{array}$ & $\begin{array}{l}\mathrm{Ca}_{\mathrm{v}} \\
\mathrm{DA}\end{array}$ & $\begin{array}{l}\text { monophosphate } \\
\text { Voltage-gated calcium channel } \\
\text { Dopamine }\end{array}$ \\
\hline & $\begin{array}{l}\text { Marcel Leist } \\
\text { marcel.leist@uni-konstanz.de }\end{array}$ & $\begin{array}{l}\text { DAT } \\
\mathrm{K}_{\mathrm{v}} \\
\text { LUHMES }\end{array}$ & $\begin{array}{l}\text { Dopamine transporter } \\
\text { Voltage-gated potassium channel } \\
\text { Lund human mesencephalic }\end{array}$ \\
\hline 1 & NMI Natural and Medical Sciences Institute at the University & MEA & Microelectrode array \\
\hline & of Tuebingen, 72770 Reutlingen, Germany & $\mathrm{Na}_{\mathrm{v}}$ & Voltage-gated sodium channel \\
\hline 2 & NMI TT GmbH, 72770 Reutlingen, Germany & $\mathrm{P} 2 \mathrm{X}$ & Ionotropic purinergic \\
\hline 3 & In Vitro Toxicology and Biomedicine, Department & $\mathrm{P} 2 \mathrm{Y}$ & Metabotropic purinergic \\
\hline & Inaugurated by the Doerenkamp-Zbinden Foundation, & pCTX & Pacific ciguatoxin \\
\hline & $\begin{array}{l}\text { University of Konstanz, Universitaetsstr. 10, } \\
78457 \text { Constance, Germany }\end{array}$ & $\mathrm{pEC}_{50}$ & $\begin{array}{l}\text { Negative logarithm of the half-maximal effec- } \\
\text { tive concentration }\end{array}$ \\
\hline & $\begin{array}{l}\text { Life Sciences Faculty, Albstadt-Sigmaringen University, } \\
72488 \text { Sigmaringen, Germany }\end{array}$ & & \\
\hline
\end{tabular}




$\begin{array}{ll}\text { pIC }_{50} & \begin{array}{l}\text { Negative logarithm of the half-maximal } \\ \text { inhibitory concentration }\end{array} \\ \text { PLO } & \text { Poly-L-ornithine } \\ \text { STX } & \text { Saxitoxin } \\ \text { TEA } & \text { Tetraethylammonium } \\ \text { TTX } & \text { Tetrodotoxin } \\ \text { VTD } & \text { Veratridine }\end{array}$

\section{Introduction}

Assessment of adverse effects on the nervous system is still a challenge for the development of drugs and for many chemicals in other industry sectors (Schmidt et al. 2017; Walker et al. 2018). It is widely accepted that misleading outputs from traditional preclinical screenings contribute to the current decline in new drug applications, and therefore, more and better tests are required. The most frequent drug side effects observed after drug marketing are related to the disturbance of nervous system function (Redfern et al. 2010). In this context, it is important to note that the toxicity of excitable tissues like the nervous system (or the heart) differs from typical toxic effects observed, e.g., in the liver. For electrically active cells, pronounced impairment can occur in the absence of any morphological changes. The undetected toxicity of drugs is still a major cause of death in the EU (Giardina et al. 2018) and the USA (Sonawane et al. 2018). Neurotoxicity and cardiotoxicity account together for nearly $60 \%$ of drug rejections during trials or post-commercialization (McNaughton et al. 2014; Onakpoya et al. 2016; Walker et al. 2018). In the case of the nervous system, functional toxicants may lead to sensory disturbances, nausea, cognitive impairment or seizures. The occurrence of such adverse effects in man is not predicted well by classical animal models (Olson et al. 2000; Mead et al. 2016), and a large consortium of pharmaceutical industry has therefore initiated the NeuroDeRisk project within the innovative medicines initiative 2 (IMI2) of the Horizon2020 framework program (https://cordis.europa.eu/project/id/821528).

Several assays have been developed that assess the capacity of test compounds to kill neurons or to affect their morphology (Forsby et al. 2009; Wilson et al. 2014; Barbosa et al. 2015; Schultz et al. 2015). Some of them have proven useful also for larger screens, or were optimized to detect specific cell damage, e.g., to mitochondria (Delp et al. 2018a, 2019). However, such assays fail to detect several functional toxicants. It is therefore important that also neurophysiological end points can be robustly assessed. One approach is to measure the effects on a large panel of known receptors, enzymes, transporters and channels that are required for neuronal function (Pottel et al. 2020). A more economic variant of this approach uses a physiological parameter that is easily measurable and relates to many of the above toxicant targets. The change of the free intracellular $\mathrm{Ca}^{2+}$ concentration $\left[\mathrm{Ca}^{2+}\right]_{\mathrm{i}}$ is such an end point. The quantification can be performed at high throughput by using live-cell fluorescence imaging of neuronal cultures loaded with calcium-sensitive dyes (Sirenko et al. 2019; Grunwald et al. 2019; Karreman et al. 2020; Brüll et al. 2020).

Two major issues have to be addressed for establishment of an assay on this basis. First, a test system is required that is sufficiently robust to allow comparisons from cell to cell, from well to well, from plate to plate and also between biological replicates (=different cell preparations/assay days). Second, neuronal network features need to be captured. Testing of individual cells alone does not fully capture the neuronal physiology. It can assess many toxicant targets, but not the coupling of neurons with one another (the major functional feature of the nervous system).

Current attempts to develop improved neurotoxicity assays tackle these two issues in different ways (Schultz et al. 2015). The main options for test systems are rat primary neurons (Forsby et al. 2009; Sandström et al. 2017; Bradley et al. 2018; Kreir et al. 2018; Millard et al. 2019), cells differentiated from pluripotent stem cells (Pei et al. 2016; Sherman and Bang 2018; Sirenko et al. 2019; Tukker et al. 2020; Brüll et al. 2020), and cell lines (Forsby et al. 2009; Krug et al. 2013; Stiegler et al. 2011; Klima et al. 2020). The latter often have the disadvantage that they do not form effective synapses. Neurons derived from iPSC have a large potential, as shown by some screen applications (Xu et al. 2013; Ryan et al. 2016; Pei et al. 2016; Brownjohn et al. 2017; Kondo et al. 2017; Sherman and Bang 2018; Sirenko et al. 2019; Tukker et al. 2020), but their maturity and reproducibility are hard to control (Handel et al. 2016; Xia et al. 2016; Volpato et al. 2018; Little et al. 2019; Volpato and Webber 2020), and costs are very high (McKernan and Watt 2013; Bravery 2015; Engle et al. 2018; Huang et al. 2019). Primary cells can form excellent networks and contain many cell types of interest. They have for a long time been the major model used for mechanistic studies (Hansson et al. 2000; Gerhardt et al. 2001). However, they are usually of rodent origin, and molecular epitopes, gene expression programs and physiological functions may differ between species (Leist and Hartung 2013).

Several approaches have been developed to test for neuronal connectivity. For instance, paired patch clamp recordings of synaptically connected pre- and post-synaptic cells allow the investigation of neuronal transmission within a local network (Kraushaar and Jonas 2000; Hefft et al. 2002). An approach that allows more throughput are microelectrode arrays (MEA) that record extracellular field potentials of spontaneously active neuronal networks (Hogberg et al. 2011; McConnell et al. 2012; Nicolas et al. 2014; Alloisio et al. 2015; Odawara et al. 2016; Vassallo et al. 2016; 
Kraushaar et al. 2017; Bader et al. 2017; Bradley et al. 2018; Kreir et al. 2018; Tukker et al. 2018, 2020). By comparison of the firing patterns measured on various electrodes in a culture dish, network synchronization parameters can be derived. This system can thus assess toxicant effects both on the (averaged) function of individual neurons (e.g., spiking activity) or on network activity and allows therefore comprehensive screens (Alloisio et al. 2015; Kraushaar et al. 2017; Bader et al. 2017; Bradley et al. 2018; Kreir et al. 2018; Tukker et al. 2018, 2020). The use of rat neurons is most established for such MEA assays, but also human iPSC neurons are increasingly being used (Odawara et al. 2016, 2018; Kraushaar et al. 2017; Tukker et al. 2018, 2020). To this date, the cost and complexity of the latter approach have prevented larger screens, and only few studies requiring at least medium throughput (concentration-response curves with several replicates and assay conditions) have been published (Odawara et al. 2016, 2018; Kraushaar et al. 2017; Tukker et al. 2020).

We therefore investigated new strategies that will lead to an in vitro neurotoxicity assay using human cells, allowing for highly reproducible assay conditions at low cost and permitting measurements on single cell function as well as on network properties. As test system basis, we used LUHMES cells, which are conditionally immortalized, but non-transformed (Gutbier et al. 2018) human neurons that are well established for morphological, metabolical and biochemical neurotoxicity testing (Krug et al. 2013, 2014; Zhang et al. 2014; Lohren et al. 2015; Smirnova et al. 2016; Harris et al. 2017; Tong et al. 2017; Witt et al. 2017; Delp et al. 2018a, b, 2019; Brüll et al. 2020). We established $\mathrm{Ca}^{2+}$-signaling as the main end point, on the population level, as well as on the level of individual cells and confirmed their basic neuroexcitability parameters. Examples are provided for the assessment of toxicants affecting ion channels, receptors and transporters with high reproducibility and data accuracy. Finally, oscillations of $\left[\mathrm{Ca}^{2+}\right]_{\mathrm{i}}$ across the entire culture dish were identified and exemplified as readout for neuronal connectivity and as a measure to identify compounds modifying neuronal network features.

\section{Materials and methods}

\section{Materials and chemicals}

An overview of experimental tool compounds and toxicants is given in table $\mathrm{S} 1$.

Pacific ciguatoxin (pCTX) isolated from a moray eel was provided by the laboratory of Richard Lewis, University of Queensland, Brisbane, Australia.

\section{Cell culture}

The cultivation of the LUHMES cells was performed as described earlier (Scholz et al. 2011; Krug et al. 2013; Schildknecht et al. 2013). In brief, LUHMES cells were cultured in standard cell culture flasks (Sarstedt) that were pre-coated with $50 \mu \mathrm{g} / \mathrm{ml}$ poly-L-ornithine (PLO) and $1 \mu \mathrm{g} /$ $\mathrm{ml}$ fibronectin (Sigma-Aldrich) in $\mathrm{H}_{2} \mathrm{O}$ overnight at $37^{\circ} \mathrm{C}$. The cells were maintained in proliferation medium containing advanced DMEM/F12 (Gibco) with $2 \mathrm{mM} \mathrm{L-glutamine}$ (Sigma Aldrich), $1 \times \mathrm{N} 2$-supplement (Gibco) and $40 \mathrm{ng} / \mathrm{ml}$ recombinant human basic fibroblast growth factor (FGF-2, $\mathrm{R} \& \mathrm{D}$ Systems). The cells were kept at $37{ }^{\circ} \mathrm{C}$ and $5 \% \mathrm{CO}_{2}$ and passaged three times a week, when the culture reached a confluency of $75-90 \%$. Cells were used until passage 18 . For differentiation, cells were cultured in differentiation medium consisting of advanced DMEM/F12 (Gibco) supplemented with $2 \mathrm{mM} \mathrm{L}$-glutamine (Sigma Aldrich), $1 \times$ N2-supplement (Gibco), 1 mM N6,2'-0-dibutyryl 3',5'-cyclic adenosine monophosphate (cAMP) (Sigma Aldrich), $1 \mu \mathrm{g} / \mathrm{ml}$ tetracycline (Sigma Aldrich) and $2 \mathrm{ng} / \mathrm{ml}$ recombinant human glial cell-derived neurotrophic factor (GDNF, R\&D Systems).

For automated patch clamp recordings, the cells were differentiated for 9 days. The medium was changed every other day, supplemented with $1 \mu \mathrm{g} / \mathrm{ml}$ laminin (Sigma Aldrich). For $\mathrm{Ca}^{2+}$-imaging, the cells were pre-differentiated for $48 \mathrm{~h}$ in cell culture flasks, detached and plated at a density of 20.000 cells per well on $0.1 \%$ PEI-coated 384-well plates (Greiner Bio-One), respectively. For manual patch clamp recordings, the cells were plated at a density of 750 cells $/ \mu 1$ on $0.1 \%$ PEI-coated glass coverslips. The cells were further differentiated for another $7-8$ days. $50 \%$ of the medium was exchanged every $2-3$ days.

\section{Dopamine uptake}

LUHMES cells were differentiated for 6 days in a 24-well format and then treated with the indicated DAT inhibitors. After $15 \mathrm{~min}$, the natural DAT substrate dopamine (DA, $10 \mu \mathrm{M})$ was added in radioactively-labeled $\left({ }^{3} \mathrm{H}, 1.5 \mathrm{~Bq} / \mathrm{mol}\right)$ form. After $10 \mathrm{~min}$ at $37^{\circ} \mathrm{C}$, the supernatant was removed and cells were washed with PBS. Then lysis buffer was added (PBS containing $0.2 \%$ Triton X-100). The amount of radioactive label taken up by the cells as well as the residual activity in the cell supernatant (plus washing buffer) was measured on a scintillation counter. All inhibitor data were normalized to the uptake of cells only exposed to solvent $\left(1.2 \pm 0.4 \mathrm{nmol} \mathrm{DA} / 10^{6}\right.$ cells $)$. 


\section{Gene expression profiling}

Five biological replicates were generated from LUHMES cells differentiated for 2, 3, 5, 6, 8, 10, and 11 days, as well as from undifferentiated LUHMES cells (day 0). These samples were prepared for transcriptome analysis considering genes of neurotransmitter receptors, ion channels, and calcium binding proteins. Samples were analyzed via the TempO-Seq assay, which is a targeted RNA sequencing method developed by BioSpyder Technologies Inc. (Carlsbad, CA, USA). The method is described in detail in House et al. (2017). For sample preparation, LUHMES grown in 96-well plates were lysed in $25 \mu \mathrm{l} \times$ BioSpyder lysis buffer according to the manufacturer's instructions. The lysate from ten wells was pooled for each sample. Samples were stored at $-80{ }^{\circ} \mathrm{C}$ before shipping on dry ice to BioClavis (BioClavis, ltd., Glasgow, UK) for TempO-Seq analysis. The resulting FASTQ files were aligned using the STAR algorithm to a pseudo-transcriptome by BioClavis and eventually normalized and standardized to a data format of $\mathrm{x}$ gene specific counts per one million reads. Traditional whole genome RNA sequencing (RNAseq) was performed for comparison and validation. Cells were cultured in six-well plates. For sample preparation, the medium was removed and cells were lysed in TriFast reagent (Peqlab, VWR, USA). The lysate of six wells was pooled for each sample. Samples were stored at $-20{ }^{\circ} \mathrm{C}$ until they were sent on dry ice to the department of toxicogenomics at the University Maastricht, The Netherlands, for RNAseq analysis.

\section{$\mathrm{Ca}^{2+}$-imaging}

$\mathrm{Ca}^{2+}$-imaging was performed using HT Functional Drug Screening System FDSS/ $\mu$ CELL (Hamamatsu Photonics) at nominal $37^{\circ} \mathrm{C}$. The FDSS/ $\mu$ Cell system enables the indirect recording of changes of intracellular $\mathrm{Ca}^{2+}\left[\mathrm{Ca}^{2+}\right]_{\mathrm{i}}$ via $\mathrm{a} \mathrm{Ca}^{2+}$-sensitive fluorescent dye. The fluorescence signal of a complete 384-well plate is acquired at once with a highspeed and high-sensitivity digital ImagEM X2 EM-CCD camera (Electron Multiplying Charge-Coupled Device, Hamamatsu Photonics), but with limited spatial resolution. Therefore, the software only determines the mean fluorescence signal of each well. The signals of individual cells could not be captured. For compound application, the integrated dispenser head with 384 pipette tips was used, which can add the test compound to all wells simultaneously. The cells were preincubated with Cal-520 AM (AAT Bioquest) at a concentration of $1 \mu \mathrm{M}$ for $1 \mathrm{~h}$ at $37^{\circ} \mathrm{C}$. For recording, the medium was exchanged by a buffer solution containing [mM]: $135 \mathrm{NaCl}, 5 \mathrm{KCl}, 0.2 \mathrm{MgCl}_{2}, 2.5 \mathrm{CaCl}_{2}, 10$ HEPES and $10 \mathrm{D}$-glucose, $\mathrm{pH}$ 7.4. Test compound application was executed after obtaining a $1.5 \mathrm{~min}$ baseline recording. Where applicable, a second application was executed $4.5 \mathrm{~min}$ after the first application. The total recording never exceeded 8 min.

\section{Automated patch clamp recordings}

Automated patch clamp recordings were performed on a QPatch (Sophion Bioscience) with 16X QPlates. After detachment, the cells were resuspended at a concentration of $3-4 \times 10^{6}$ cells per $\mathrm{ml}$. The extracellular solution contained [in $\mathrm{mM}$ ]: $145 \mathrm{NaCl}, 4 \mathrm{KCl}, 10 \mathrm{CaCl}_{2}, 10$ HEPES, 20 TEA, $14-\mathrm{AP}$ and $0.1 \mathrm{Cd}^{2+}, \mathrm{pH}$ 7.4. The intracellular solution contained [in $\mathrm{mM}$ ]: $120 \mathrm{CsF}, 20 \mathrm{CsCl}, 5 \mathrm{NaCl}, 10$ HEPES and 10 EGTA, pH 7.2. Recordings were obtained at room temperature. Between test pulses, the cells were held in whole-cell clamp at a holding potential of $-80 \mathrm{mV}$. For TTX and lidocaine experiments, cells were hyperpolarized to $-120 \mathrm{mV}$ for $200 \mathrm{~ms}$, before they were depolarized with ten pulses to $0 \mathrm{mV}$ for $10 \mathrm{~ms}$ with an interval of $100 \mathrm{~ms}$ between each pulse. For the recordings with ICA-121431, a selective voltage-gated sodium channel $\left(\mathrm{Na}_{\mathrm{V}}\right)$ antagonist, a pulse protocol was used which inactivated $50 \%$ of the $\mathrm{Na}_{\mathrm{V}}$ channels to achieve a selective inhibition of the $\mathrm{Na}_{\mathrm{V}}$ channels (McCormack et al. 2013). Therefore, a pre-pulse to $-55 \mathrm{mV}$ for $500 \mathrm{~ms}$ was applied corresponding to the halfinactivation voltage of the cells' $\mathrm{Na}_{\mathrm{V}}$ channels, followed by a test pulse to $0 \mathrm{mV}$ for $10 \mathrm{~ms}$. The holding potential between the pulses was $-120 \mathrm{mV}$. For the biophysical characterization of the activation properties of $\mathrm{Na}_{\mathrm{V}}$, the cells were kept at a holding potential of $-90 \mathrm{mV}$. Prior to the test pulse, the cells were hyperpolarized to $-120 \mathrm{mV}$ for $200 \mathrm{~ms}$. The test pulse had a duration of $100 \mathrm{~ms}$ and was increased from $-70 \mathrm{mV}$ to $+40 \mathrm{mV}$ in $+10 \mathrm{mV}$ steps. To examine the characteristics of the steady-state inactivation of $\mathrm{Na}_{\mathrm{V}}$, the cells were stimulated with a test pulse to $0 \mathrm{mV}$ for $10 \mathrm{~ms}$ after a pre-pulse with voltage steps from $-110 \mathrm{mV}$ to $-10 \mathrm{mV}$ in $+10 \mathrm{mV}$ steps, which lasted for $500 \mathrm{~ms}$. The recovery from inactivation of $\mathrm{Na}_{\mathrm{V}}$ was investigated as follows: cells were held at a potential of $-120 \mathrm{mV}$ followed by a first reference test pulse to $0 \mathrm{mV}$ for $200 \mathrm{~ms}$, which was followed by a second test pulse to $0 \mathrm{mV}$ for $20 \mathrm{~ms}$. The time between the two test pulses was increased from $1 \mathrm{~ms}$ with a factor of 2.5 in nine steps.

\section{Manual patch clamp recordings}

Manual patch clamp was executed with an EPC 10 USB patch clamp amplifier and PatchMaster Software (version $2 \times 90.5$; HEKA Elektronik, Lambrecht, Germany). Extracellular solution contained $[\mathrm{mM}]: 140 \mathrm{NaCl}, 4 \mathrm{KCl}, 1 \mathrm{MgCl}_{2}$, $1.8 \mathrm{CaCl}_{2}, 10 \mathrm{HEPES}$ and $10 \mathrm{D}$-glucose, $\mathrm{pH}$ 7.4. Intracellular solution contained [mM]: $107 \mathrm{~K}$-gluconate, $10 \mathrm{KCl}, 1$ $\mathrm{MgCl}_{2}, 10$ HEPES, 5 EGTA, $4 \mathrm{Na}_{2}$ ATP and $0.2 \mathrm{NaGTP}, \mathrm{pH}$ 
7.20. Recordings were obtained at room temperature. The cells were kept at a holding potential of $-70 \mathrm{mV}$. In voltage clamp mode $\mathrm{Na}_{\mathrm{V}}$ and voltage-gated potassium $\left(\mathrm{K}_{\mathrm{V}}\right)$ channels were activated for $300 \mathrm{~ms}$ by voltage pulses ranging from -70 to $+70 \mathrm{mV}$ in $+10 \mathrm{mV}$ steps after a hyperpolarizing step to $-120 \mathrm{mV}$ for $200 \mathrm{~ms}$. To investigate the firing behavior, cells were stimulated in current clamp mode by hyper- and depolarizing current pulses of $300 \mathrm{~ms}$ duration. The pulse protocol was executed at $0.2 \mathrm{~Hz}$. For agonist tests in current clamp and voltage clamp mode, cells were kept at a holding potential of $-70 \mathrm{mV}$ and the compounds were applied for $5 \mathrm{~s}$.

\section{Data analysis}

After offset correction using the FDSS software (version 3.2), the $\mathrm{Ca}^{2+}$-imaging data were exported and further analyzed with scripts written in $\mathrm{R}$ (version 3.6.3) ( $\mathrm{R}$ Core Team 2020). The concentration-response curves were fitted using a log-logistic model described by Ritz et al. (2015), utilizing the R package $d r c$ with its function $d r m$ () and LL2.2() with the following equation: $f(x)=d$ l $[1+\exp (b(\log (x)-\tilde{e}))]($ Ritz et al. 2015). The logarithm of the half-maximal effective concentration $\left(\log \mathrm{EC}_{50}\right)$ between 0 and the upper limit $(d)$, which was set to 1 , is represented by $\tilde{e}, x$ denotes the concentration and $b$ stands for the slope parameter (Ritz et al. 2015). In cases with normalizations to responses induced by another compound, the function $L L 2.3$ () was used with a variable upper limit ( $d$; Ritz et al. 2015). The same equation was used to determine the half-maximal inhibitory concentration $\left(\log \mathrm{IC}_{50}\right)$. Then the $\log \mathrm{EC}_{50}$ and $\log \mathrm{IC}_{50}$ values were converted into the $\mathrm{pIC}_{50}$ and $\mathrm{pEC}_{50}$ values, which are the negative logarithms to base 10 .

Automated patch clamp data were pre-processed using the QPatch Assay Software (version 5.0) (Sophion Bioscience, DK) for offset correction and to detect the peak currents of the $\mathrm{Na}_{\mathrm{V}}$ channels. For further analysis, scripts written in $\mathrm{R}$ were utilized. For the calculation of the voltage-dependent conductance $\left(G / G_{\max }\right)$, the peak currents $(I)$ were divided by the difference of the stimulation voltage $(V)$ and the reversal potential $\left(V_{\text {rev }}\right)$ using the equation: $G=I /\left(V-V_{\text {rev }}\right)$ and then normalized to the maximal conductance $\left(G_{\max }\right.$; Cheng et al. 2011; Zhang et al. 2013; Wang et al. 2015). For steady-state inactivation $\left(I / I_{\max }\right)$, the peak currents were normalized to the maximal peak current. The analyzed data of the voltage-dependent conductance $\left(G / G_{\max }\right)$ and the steady-state inactivation $\left(I / I_{\max }\right)$ of $\mathrm{Na}_{\mathrm{V}}$ were fitted with the Boltzmann equation: $G / G_{\max }$ and $I / I_{\max }=1 /\left(1+\exp \left[\left(V_{50}-V\right) / k\right]\right)$, which was used to estimate the half-maximal voltage $\left(V_{50}\right)$ and the slope factor ( $k$; Cheng et al. 2011; Zhang et al. 2013; Wang et al. 2015). For the analysis of the recovery from inactivation, the peak current of the second test pulse $\left(I_{\text {peak } 2}\right)$ of each time interval was normalized to the peak current of the first reference test pulse $\left(I_{\text {peak } 1}\right)$ of the corresponding time interval. Data were fitted with a bi-exponential function resulting in a fast and a slow time constant using the equation: $I_{\text {peak } 2} / I_{\text {peak } 1}=A_{1}\left[1-\exp \left(-t / \tau_{1}\right)\right]+A_{2}\left[1-\exp \left(-t / \tau_{2}\right)\right]($ Zhang et al. 2013). The parameter $t$ stands for the time interval, $A_{1}$ and $A_{2}$ are the amplitudes and $\tau_{1}$ and $\tau_{2}$ represent the recovery time constants.

The raw data of the manual patch clamp recordings were analyzed in scripts written in R. For leak subtraction, the P/4 algorithms of PatchMaster and QPatch Software were used in the voltage clamp recordings for manual and automated patch clamp experiments, respectively.

The following $\mathrm{r}$ packages were utilized for data handling: cowplot (Wilke 2019), dplyr (Wickham et al. 2020), drc (Ritz et al. 2015), ephys2 (Danker 2018), ggplot2 (Wickham 2016), htmlwidgets (Vaidyanathan et al. 2019), lemon (Edwards 2019), magick (Ooms 2020), magrittr (Bache and Wickham 2014), matrixStats (Bengtsson 2020), miniUI (Cheng 2018), modelr (Wickham 2020), multcomp (Hothorn et al. 2008), plotrix (Lemon 2006), proto (Grothendieck et al. 2016), shiny (Chang et al. 2020), shinyjs (Attali 2020), shinyTree (Trestle Technology, LLC 2017), tidyverse (Wickham et al. 2019).

The raw count tables of gene expression profiling with TempO-Seq assay and traditional whole genome RNA sequencing (RNAseq) were analyzed with the $\mathrm{R}$ package DESeq2 (v1.24.0) (Love et al. 2014). RNAseq counts were normalized to the library size and the transcript length (Transcripts per kilobase million (TPM)) (Wagner et al. 2012). TempoSeq counts were normalized to total counts per sample [counts per million (CPM)]. Gene lengths were retrieved from the hg18 reference genome (NCBI Build 36.1) with the R package Goseq (v1.40.0) (Young et al. 2010). TPM/CPM were averaged over the five biological replicates.

\section{Data handling and statistics}

Unless mentioned differently, values are presented as mean \pm SEM. If not indicated otherwise, experiments were performed with at least three technical replicates per condition. Detailed data on $\mathrm{pEC}_{50}, \mathrm{pIC}_{50}$ and n numbers are found in supplementary tables. Statistical significance was defined as $P<0.05$ and was determined by one-way ANOVA with Dunnett's post hoc test as indicated. 


\section{Results and discussion}

\section{Implementation of high-throughput $\mathrm{Ca}^{2+}$-signaling and application to purinergic receptor profiling}

A neurofunctional test should ideally be able to assess neuronal activity changes related to various effector systems that directly affect the membrane potential, and thus the neuronal firing properties. Some of the most important toxicant targets are voltage-dependent ion channels, ligand-gated ion channels and electrogenic transporters. The classical neurotoxicological approach uses electrophysiological techniques. These are resource intensive, can only be performed with equipment not readily available in most cell culture laboratories, and require specialist knowledge to perform and interpret the experiments. We explored here whether an imaging-based approach could be used alternatively to capture various neuronal responses in a high-throughput fashion. Notably, the term "high throughput" is here not meant to imply assessment of very large compound collections. We rather see it as important to allow good in vitro toxicology practice, i.e., recording of full concentration-response curves with sufficient replicates (i.e., at least 20-30 data points per compound). Such data sets are still hard (or very expensive) to obtain with patch clamp approaches or microelectrode arrays (MEA). As readout, we used here the rapid changes (peaks) of $\left[\mathrm{Ca}^{2+}\right]_{\mathrm{i}}$, because this can be measured easily by imaging devices (in cells loaded with fluorescent indicators), and as this end point is sensitive to changes in the membrane potential that lead to action potentials in neurons.

Initially, we explored purinergic (P2) receptors as example for ligand-gated ion channels. They play an important role in neurons of the peripheral and central nervous system. The P2X family, the focus of our experiments, is present in different types of neurons, for example in dopaminergic neurons. They take various roles in pathological conditions like Parkinson's disease and in pain mediation (Burnstock and Kennedy 1985; Khakh et al. 2001; Abbracchio et al. 2006; Amadio et al. 2007; Syed and Kennedy 2012; Puchałowicz et al. 2014; Tóth et al. 2019).

To obtain reference data, we performed manual patch clamp recordings to investigate the presence of $\mathrm{P} 2 \mathrm{X}$ receptors on a single-cell level. LUHMES cells were plated on glass coverslips, where they adhered and extended long neurites (Fig. 1a). The application of ATP triggered action potential firing (Fig. S1A), associated with fast-inactivating inward currents (Fig. S1B). The shape of the current curves indicates the presence of $\mathrm{P} 2 \mathrm{X} 1$ or $\mathrm{P} 2 \mathrm{X} 3$ receptors (Bianchi et al. 1999; Koshimizu et al. 2000; North 2002; Li et al. 2013). More detailed follow-up experiments suggest that also some receptors with slow inactivation kinetics (e.g.,
P2X4 or P2X7) (Bianchi et al. 1999; Koshimizu et al. 2000; North 2002; Li et al. 2013) may be present (Fig. S1C, D). Gene expression studies on the LUHMES cells confirmed the presence of mRNA of several P2X receptors (Fig. S2), with $\mathrm{P} 2 \mathrm{X} 3$ appearing to be dominant.

On this basis, we tried to assess the responses induced by the activation of $\mathrm{P} 2 \mathrm{X}$ receptors using $\mathrm{Ca}^{2+}$-imaging. LUHMES loaded with a $\left[\mathrm{Ca}^{2+}\right]_{\mathrm{i}}$ indicator dye were exposed to the endogenous P2X receptor agonist ATP (Fig. 1b) and the synthetic ATP analog BzATP (Fig. 1c) (Bianchi et al. 1999; Khakh and North 2012). A strong signal peak was recorded, and the fast decrease of the fluorescence signal (half-life of $\sim 8 \mathrm{~s}$ at $100 \mu \mathrm{M}$ ATP) found here is typical for $\mathrm{P} 2 \mathrm{X} 1$ and $\mathrm{P} 2 \mathrm{X} 3$ receptors as reported previously in GT1-7 cells (Koshimizu et al. 2000; He et al. 2003) (Fig. 1b). We obtained $\mathrm{pEC}_{50}$ values from seven-point concentration-response curves ( $n=42$ data points per compound) (Fig. 1d), and these were well in line with published data for human $\mathrm{P} 2 \mathrm{X} 1$ and $\mathrm{P} 2 \mathrm{X} 3$ receptors.

As our results suggest a strong contribution of $\mathrm{P} 2 \mathrm{X} 1$ and $\mathrm{P} 2 \mathrm{X} 3$ to the responses induced by ATP, we used this as an example for a mechanistic follow-up of an observed effect. A specific agonist of these receptors (i.e., $\alpha, \beta$-meATP) was employed to confirm their involvement (Burnstock and Kennedy 1985; Abbracchio and Burnstock 1994; Bianchi et al. 1999; Gever et al. 2006; Khakh and North 2012). We first obtained reference data by manual patch clamp. The electrophysiological responses (Fig. S3A, B) suggested the activation of $\mathrm{P} 2 \mathrm{X} 1$ and $\mathrm{P} 2 \mathrm{X} 3$ receptor subtypes (Bianchi et al. 1999; Koshimizu et al. 2000; Burgard et al. 2000; North 2002; Li et al. 2013). The selective agonist $\alpha, \beta$-meATP also led to a cellular response in $\mathrm{Ca}^{2+}$-imaging experiments (Fig. $\mathrm{S} 3 \mathrm{C})$. The recordings were performed for five differentiations at seven concentrations to illustrate the reproducibility of the test system and end point (Fig. S3D). The $\mathrm{pEC}_{50}$ value of 7.5 (Fig. 1e) and the fast inactivation of the fluorescence signal (Fig. S3C) confirmed a functional expression of P2X1 and/or P2X3 receptors (Bianchi et al. 1999; Gever et al. 2006).

For a biological calibration of the $\alpha, \beta$-meATP signal, we compared it to the signal triggered by an increase in the buffer $\mathrm{K}^{+}$concentration (maximal depolarizing stimulus). The response evoked by the purinergic agonist reached up to $28 \%$ of the $\mathrm{K}^{+}$-induced signal intensity. This is well in line with $\mathrm{P} 2 \mathrm{X}$ receptor activation being a physiological response that does not reach the level of complete and irreversible cell depolarization (Fig. S3E, F).

As a next step to characterize the suitability of the test system, we studied interference with $\mathrm{Ca}^{2+}$-signaling. The antagonistic effect of TNP-ATP (competitive antagonist) on the response to ATP and $\alpha, \beta$-meATP was compared in $\mathrm{Ca}^{2+}$-imaging experiments (Fig. 2a). At high concentrations, we observed a complete block of signaling, and the 


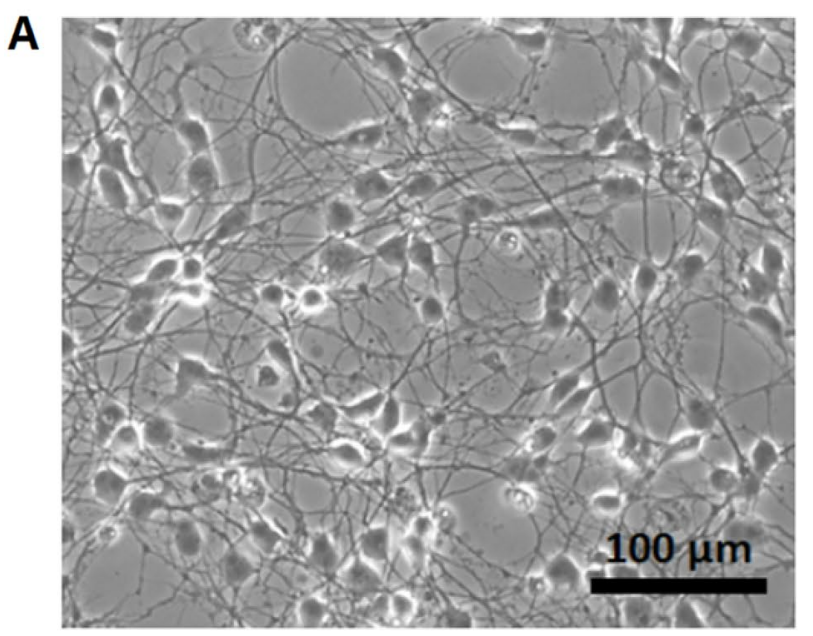

D

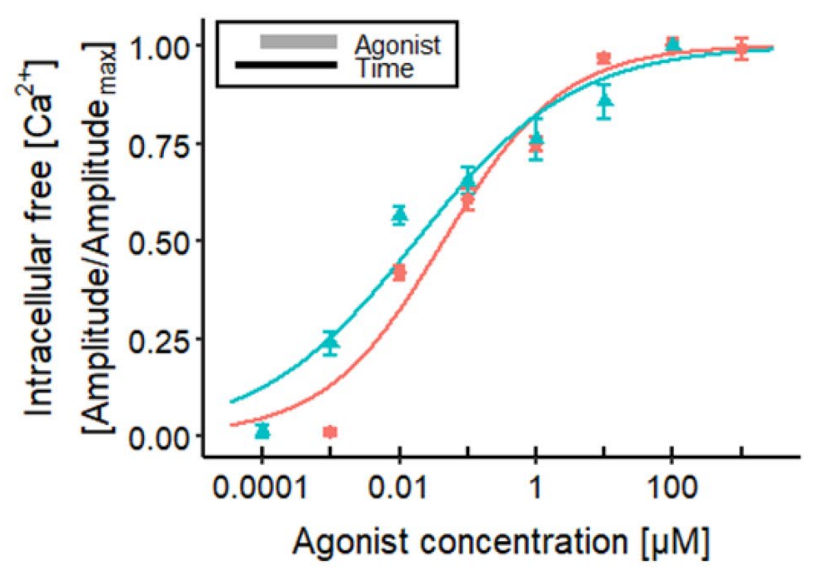

Fig. 1 Effects of different P2 receptor agonists. a LUHMES cells were differentiated for 7 days on a pre-coated glass coverslip before a phase contrast image was taken. $\mathbf{b}, \mathbf{c} \mathrm{Ca}^{2+}$-imaging traces displaying the responses of the LUHMES neurons to the application of $\mathbf{b}$ ATP and c BzATP. d The concentration-response curves yield $\mathrm{pEC}_{50} \mathrm{~S}$ of $7.35 \pm 0.08$ for ATP and 7.76 \pm 0.11 for BzATP in $\mathrm{Ca}^{2+}$-imaging. e Concentration-dependent effect of $\alpha, \beta$-meATP in $\mathrm{Ca}^{2+}$-imaging,

concentration-response features of the antagonist were agonist dependent, as expected for a competitive inhibitor. The significant difference of $\mathrm{pIC}_{50}$ values (6.1 and 7.5) suggests that ATP stimulates a broad panel of P2X receptors (for some of which TNP-ATP has a relatively low affinity) (Virginio et al. 1998; Gever et al. 2006). To further explore how well such differential antagonist effects can be described and quantified, we used a selective antagonist of $\mathrm{P} 2 \mathrm{X} 3$ receptors, A-317491 (Virginio et al. 1998; Gever et al. 2006). This compound potently and completely blocked the response to $\alpha, \beta$-meATP, while it showed only a weak partial effect on ATP signals (Fig. 2b).
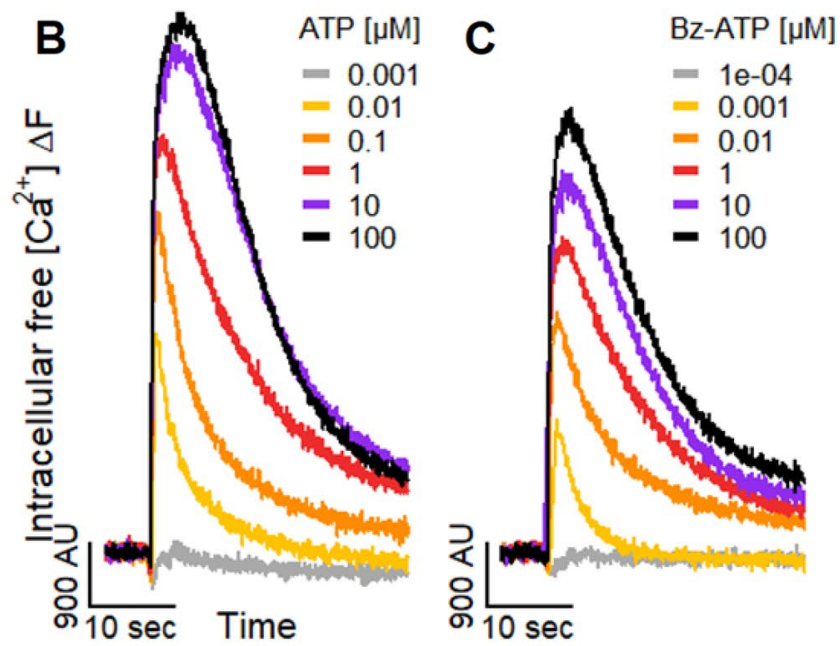

E

$-\alpha, \beta-$ meATP

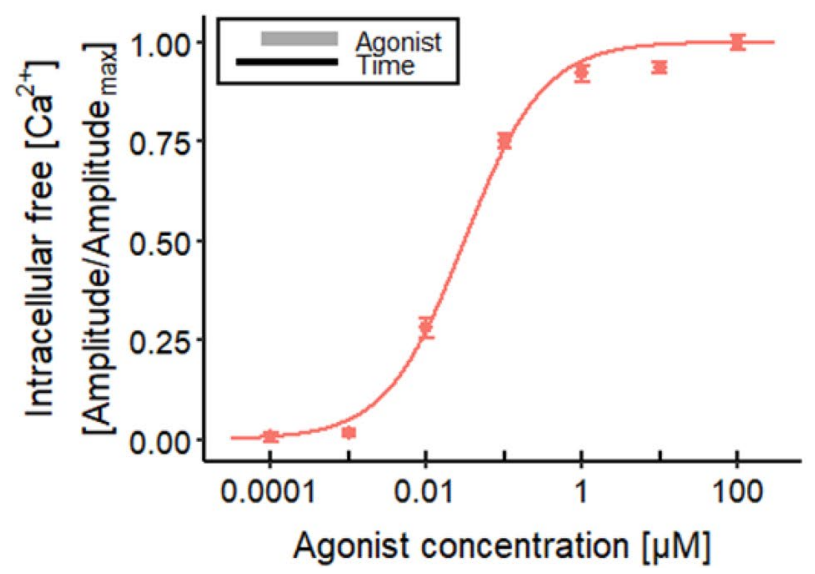

resulting in a $\mathrm{pEC}_{50}$ value of $7.52 \pm 0.03$. The concentration-response curve depicts the mean of five differentiations of the LUHMES neurons. See Fig. S3D for more details on the curves of the single differentiations. Note the treatment schemes (upper left corner), illustrating the experimental design. Detailed data on $\mathrm{n}$ numbers are found in table S4

It needs to be noted here that ATP, but not $\alpha, \beta$-meATP, can also activate P2Y receptors (Abbracchio et al. 2006; von Kügelgen and Harden 2011), for example P2Y1 (Palmer et al. 1998; Waldo and Harden 2004) and P2Y11 receptors (Communi et al. 1999; Qi et al. 2001; White et al. 2003), which are also expressed in LUHMES neurons and which may theoretically act as response modifiers (Fig. S2).

Finally, we used the antiprotozoal agent suramin to show applicability of the LUHMES system to characterize xenobiotics potentially interfering with $\mathrm{P} 2 \mathrm{X}$ receptors. One known side effect of suramin, a drug used for the treatment of sleeping sickness (Wéry 1994; Kennedy 
Fig. 2 Characterization of $\mathrm{P} 2 \mathrm{X}$ receptors. $\mathrm{Ca}^{2+}$-imaging experiments researching the effects of different $\mathrm{P} 2 \mathrm{X}$ receptor antagonists on the response of LUHMES cells triggered by $1 \mu \mathrm{M}$ ATP $\left(\sim \mathrm{EC}_{75}\right.$, Fig. 1d) and $0.1 \mu \mathrm{M} \alpha, \beta$-meATP ( $\sim \mathrm{EC}_{75}$, Fig. 1e). a The responses were blocked concentration-dependently by TNP-ATP with $\mathrm{pIC}_{50} \mathrm{~s}$ of $6.05 \pm 0.06$ for ATP and of $7.50 \pm 0.05$ for $\alpha, \beta$-meATP. The values are significantly different. b A-317491 blocked the responses of ATP up to $40 \%$ and yielded a $\mathrm{pIC}_{50}$ for $\alpha, \beta$-meATP of $6.31 \pm 0.05$. $\mathrm{c}$ An inhibitory effect of suramin could be detected for ATP and $\alpha, \beta$-meATP, which resulted in $\mathrm{pIC}_{50} \mathrm{~s}$ of $4.09 \pm 0.03$ and $4.51 \pm 0.03$, respectively. Note the treatment schemes (lower left corner), illustrating the experimental design. Detailed data on $n$ numbers are found in table S4

2013), is the inhibition of P2X receptors (Garcia-Guzman et al. 1997; Gever et al. 2006; Coddou et al. 2011; Khakh and North 2012). The experiments yielded $\mathrm{pIC}_{50} \mathrm{~s}$ of 4.1 for ATP and 4.5 for the P2X3 ligand $\alpha, \beta$-meATP (Fig. $2 \mathrm{c}$ ). The data obtained with $\alpha, \beta$-meATP agree with a previously reported $\mathrm{pIC}_{50}$ of approximately 4.8 for human $\mathrm{P} 2 \mathrm{X} 3$ receptors (Garcia-Guzman et al. 1997).

In summary, these initial experimental system evaluations confirmed that measurement of $\left[\mathrm{Ca}^{2+}\right]_{\mathrm{i}}$ in LUHMES can capture (some) electrophysiological responses related to drug effects and toxicity. The data available at this stage indicate that the potency quantifications for agonists and antagonists are precise (little variation between cell preparations) and exact (very similar to reference systems).

\section{Characterization of $\mathrm{Na}_{\mathrm{V}}$ channel toxicants}

Next, we moved to the detection of potential channel modulators and checked whether agents affecting voltage-dependent sodium channels $\left(\mathrm{Na}_{\mathrm{V}}\right.$ channels) could be characterized by $\mathrm{Ca}^{2+}$-imaging. $\mathrm{Na}_{\mathrm{V}}$ channels are essential for the onset of action potentials and thus are of critical importance for the neuronal electrical activity. An alteration of their function can lead to severe functional neurotoxicity, even with lethal consequences on the level of the organism (Lehane and Lewis 2000; Gaillard and Pepin 2001; Nicholson and Lewis 2006; Llewellyn 2009; Wiese et al. 2010; Vilariño et al. 2018; Anwar et al. 2018). $\mathrm{Na}_{\mathrm{V}}$ channels couple to $\left[\mathrm{Ca}^{2+}\right]_{\mathrm{i}}$ indirectly by triggering cell depolarization, which in turn leads to the opening of voltage-dependent calcium channels and thus an influx of $\mathrm{Ca}^{2+}$ into neurons (Vetter et al. 2012; Mohammed et al. 2017).

To check practical applicability, we studied the $\mathrm{Ca}^{2+}$-response of well-known $\mathrm{Na}_{\mathrm{V}}$ channel toxicants. First, veratridine (VTD), a plant alkaloid (Ulbricht 1998; Wang and Wang 2003) known to delay $\mathrm{Na}_{\mathrm{V}}$ channel inactivation (Catterall 1992; Power et al. 2012; Tsukamoto et al. 2017; Zhang et al. 2018), was used. For background information, patch clamp data were obtained and VTD reversibly increased the action potential duration (Fig. 3a). Imaging experiments then showed a concentration-dependent rise of $\left[\mathrm{Ca}^{2+}\right]_{\mathrm{i}}$ that resulted in a $\mathrm{pEC}_{50}$ value of 5.4 for VTD
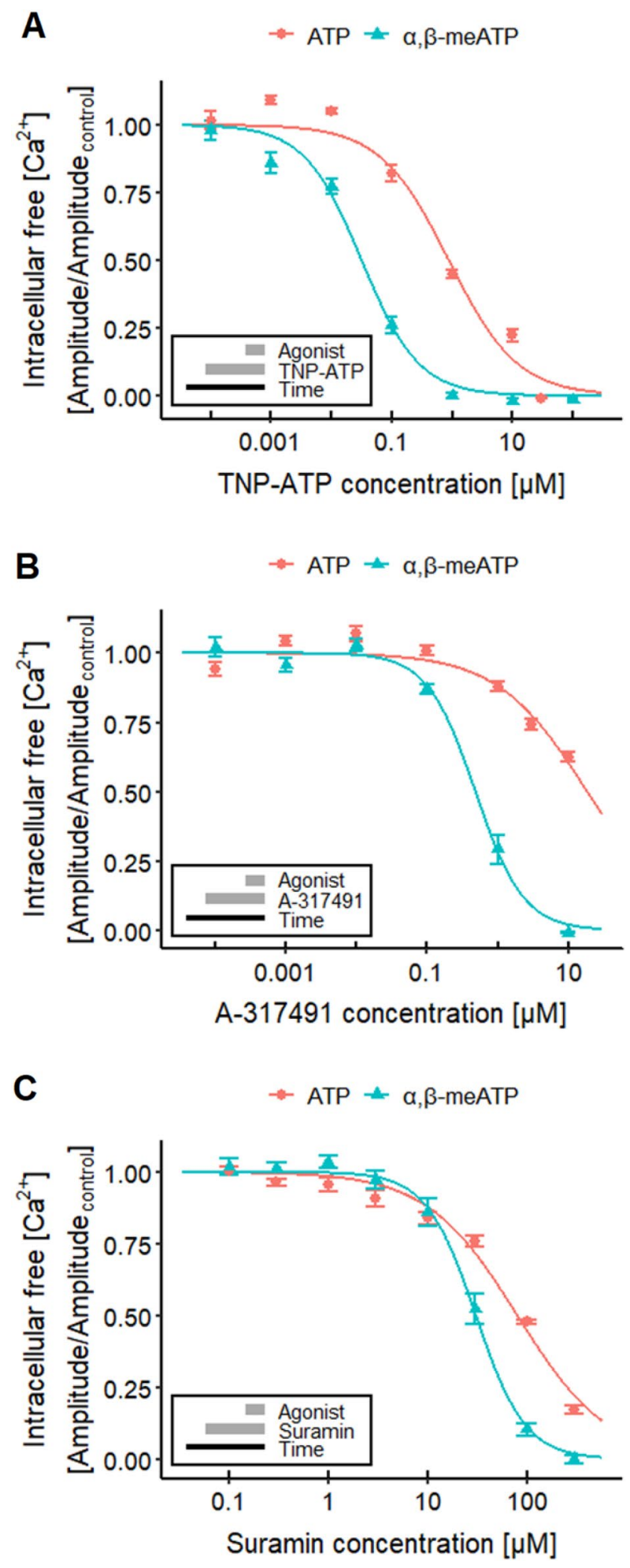

(Fig. 3b). These data are in good agreement with published data on human SH-SY5Y cells (Vetter et al. 2012). Also here, we moved on to also study antagonism: VTD-induced responses were blocked by the $\mathrm{Na}_{\mathrm{V}}$ channel antagonist tetrodotoxin (TTX, Fig. S4A) with a $\mathrm{pIC}_{50}$ of 7.9 (Fig. 3c). The inhibition of VTD-mediated effects by TTX is 

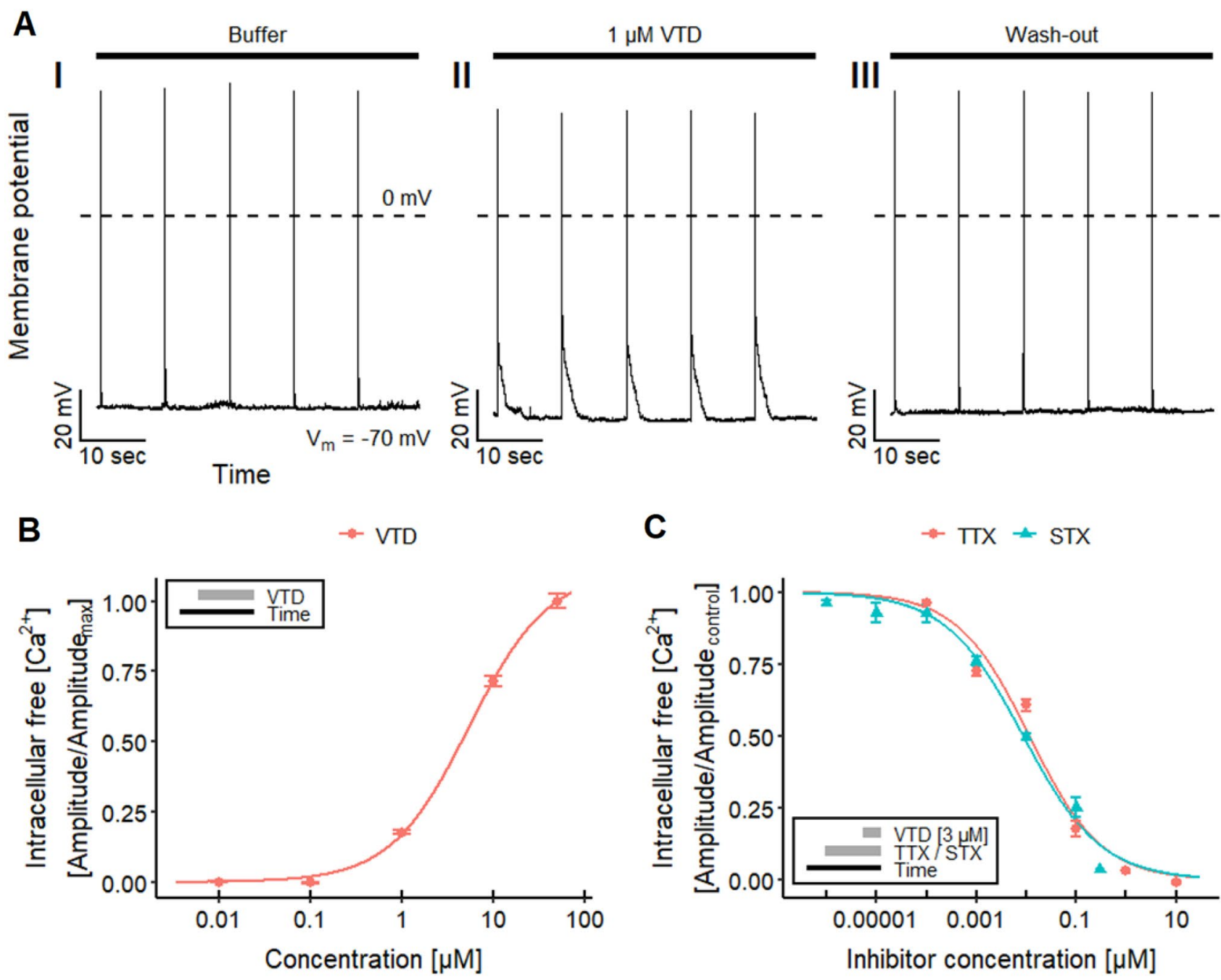

Fig. $3 \mathrm{Na}_{\mathrm{V}}$ channel toxicity-effect of veratridine (VTD). a Traces of a manual patch clamp experiments with LUHMES neurons showing five action potentials, triggered by $10 \mathrm{~ms}$ depolarizing current pulses with $0.1 \mathrm{~Hz}$, in untreated control (I), in the presence of $1 \mu \mathrm{M}$ veratridine (VTD, II) and after wash-out (III, $n=4)$. VTD reversibly increased the action potential duration. $\mathbf{b ~} \mathrm{Ca}^{2+}$-imaging experiments demonstrating the concentration-dependent effects of VTD

consistent with previously reported data from patch clamp recordings on rat hippocampal neurons (Alkadhi and Tian 1996), $\mathrm{Ca}^{2+}$-imaging experiments on mouse DRG neurons (Mohammed et al. 2017) and human SH-SY5Y cells (Vetter et al. 2012).

As additional proof-of-concept test compound, we used saxitoxin (STX), an alkaloid that is produced by certain genera of cyanobacteria and marine dinoflagellates (Deeds et al. 2008; Westrick et al. 2010; Wiese et al. 2010; He et al. 2016). It can contaminate water supplies and accumulate in the marine food chain, and thus cause paralytic shellfish poisoning in humans (Deeds et al. 2008; Wiese et al. 2010; Durán-Riveroll and Cembella 2017). Like TTX, STX on LUHMES neurons, which yielded a $\mathrm{pEC}_{50}$ value of $5.38 \pm 0.03$. c Concentration-dependent inhibitory effect of TTX and STX on the response triggered by $3 \mu \mathrm{M} \mathrm{VTD}$, resulting in $\mathrm{pIC}_{50}$ values of $7.93 \pm 0.06$ for TTX and $8.06 \pm 0.06$ for STX. Note the treatment schemes, illustrating the experimental designs. Detailed data on $n$ numbers are found in table $\mathrm{S} 4$

is known for its inhibitory effect on the $\mathrm{Na}_{\mathrm{V}}$ channels (Noda et al. 1989; Terlau et al. 1991; Llewellyn 2009; Mattei and Legros 2014; Durán-Riveroll and Cembella 2017). We tested the effect of STX on the response evoked by $3 \mu \mathrm{M}$ VTD to verify the capability of our assay to detect $\mathrm{Na}_{\mathrm{V}}$ channel-modulating biotoxins (Fig. S4B). The $\mathrm{pIC}_{50}$ value of 8.1 (Fig. 3c) found here is comparable to data previously described for recordings with rat $\mathrm{Na}_{\mathrm{V}} 1.2$ expressed in Xenopus laevis oocytes (Noda et al. 1989). These results demonstrate the capability of setting up a LUHMES cell-based assay for the detection of biotoxins, which affect $\mathrm{Na}_{\mathrm{V}}$ channel activity, and the quantification of their effects, using $\mathrm{Ca}^{2+}$-imaging. 

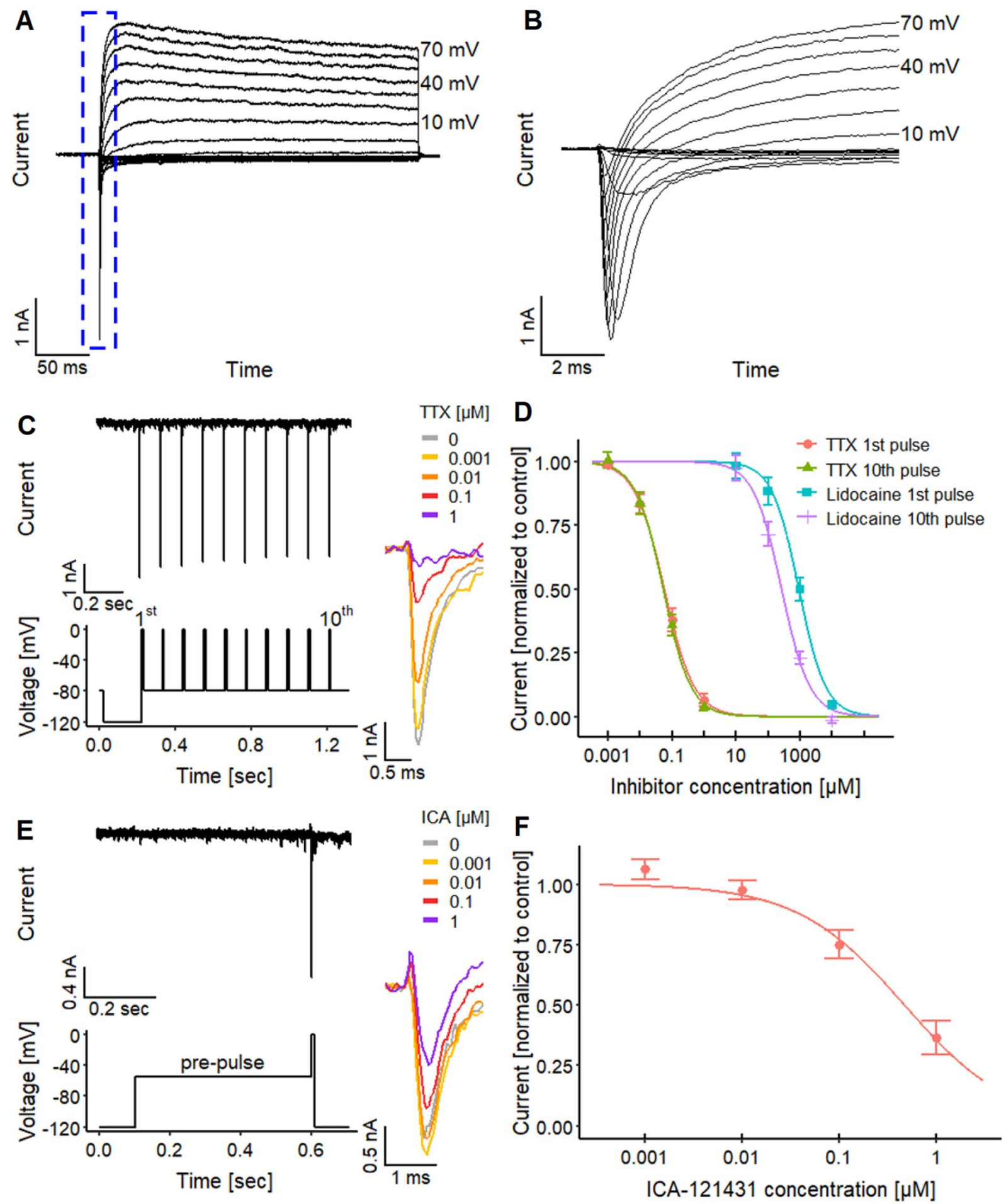

To further evaluate the usability of LUHMES cells as relevant functional neurotoxicity model, we examined the effect of pacific ciguatoxin-2 (pCTX-2) on the LUHMES cells via $\mathrm{Ca}^{2+}$-imaging (Fig. $\mathrm{S} 4 \mathrm{C}-\mathrm{E}$ ). The ciguatoxins are marine biotoxins synthetized by dinoflagellates (Lehane and Lewis 2000; Nicholson and Lewis 2006; Litaker et al. 2010, 2017; Vilariño et al. 2018). These polycyclic ethers

accumulate in the marine food chain and can lead to intoxications in humans, called ciguatera, after consumption of CTX-contaminated fish (Lehane and Lewis 2000; Nicholson and Lewis 2006; Dickey and Plakas 2010; Skinner et al. 2011; Vilariño et al. 2018). The CTXs comprise several analogs, with an acute toxicity (mice) of pCTX-2 of $2.3 \mu \mathrm{g} / \mathrm{kg}$ (Lewis et al. 1991; Lehane and Lewis 2000; Nicholson and 
४Fig. 4 Electrophysiological characteristics of $\mathrm{Na}_{\mathrm{V}}$ channel. a, b Manual patch clamp recordings of a activation of voltage-gated inward and outward currents stimulated by different voltage steps with $\mathbf{b}$ a magnification of the inward current (note: different time axis). c-f Automated patch clamp recordings for a pharmacological characterization of voltage-gated $\mathrm{Na}^{+}\left(\mathrm{Na}_{\mathrm{V}}\right)$ channels, using $\mathbf{c}, \mathbf{d}$ TTX and lidocaine to investigate the use-dependent and acute inhibitory effects and e, f ICA-121431 to narrow $\mathrm{Na}_{\mathrm{V}}$ channel subtypes down. e Exemplary trace of the inward current triggered by the pulse protocol with ten closely spaced test pulses. Traces on the right depict the concentration-dependent effect of TTX on the 1st pulse. d Concentrationresponse curves yielded $\mathrm{pIC}_{50}$ values of $7.23 \pm 0.05$ (1st pulse) and $7.26 \pm 0.05$ (10th pulse). Lidocaine had $\mathrm{pIC}_{50}$ values of $3.03 \pm 0.07$ (1st pulse) and $3.57 \pm 0.06$ (10th pulse). The $\mathrm{pIC}_{50}$ values for lidocaine are significantly different, unlike the $\mathrm{pIC}_{50}$ values of TTX. e To ensure a selective effect of ICA-121431, measurements need to be performed under conditions where $50 \%$ of the $\mathrm{Na}_{\mathrm{V}}$ channels are inactivated (McCormack et al. 2013). This was achieved by the application of a prepulse to $-55 \mathrm{mV}$ before the stimulus, the determined $\mathrm{V}_{50}$ value for steady-state inactivation in these cells (Fig. S5F). Traces on the right depict the concentration-dependent effect of ICA-121431. f Effect of ICA-121431 with a $\mathrm{pIC}_{50}$ value of $6.33 \pm 0.10$. Detailed data on $n$ numbers are found in table $\mathrm{S} 4$

Lewis 2006). We found in LUHMES neurons that $15 \mathrm{nM}$ pCTX-2 increased $\left[\mathrm{Ca}^{2+}\right]_{\mathrm{i}}$. This response was followed by long-lasting oscillations of the $\mathrm{Ca}^{2+}$-imaging signal. The initial increase of the baseline $\mathrm{Ca}^{2+}$ level is likely explained by $\mathrm{Na}^{+}$influx, followed by entry of $\mathrm{Ca}^{2+}$ into the cytosol through $\mathrm{Ca}_{\mathrm{V}}$ channels (Molgó et al. 1993). The oscillation of the $\mathrm{Ca}^{2+}$-imaging signal is noteworthy as our data are not single-cell recordings, but measures of $\left[\mathrm{Ca}^{2+}\right]_{\mathrm{i}}$ in all cells of the whole neuronal network. It is thus a first indication of synchronized activity of the LUHMES neuron population (see more details below). Notably, it has been shown earlier that CTX-1 can induce oscillations of the membrane potential and repetitive firing of action potentials in other cells (Bidard et al. 1984; Hamblin et al. 1995; Hogg et al. 1998, 2002; Birinyi-Strachan et al. 2005).

Finally, we also explored the effects of a microcystin to test for the specificity of the LUHMES test system. Microcystins are cyclic peptides produced by a number of cyanobacteria genera (Sivonen and Jones 1999; He et al. 2016) found for example in contaminated water and fish (Campos and Vasconcelos 2010). They inhibit protein phosphatases, like PP1 and PP2A (MacKintosh et al. 1990; Campos and Vasconcelos 2010), but are not known to affect ion channels. We therefore anticipated that microcystin-LF (a potent hepatotoxicant) would not alter the response of the LUHMES cells. We tested the effect of a high concentration of $2 \mu \mathrm{M}$ microcystin-LF, alone and on the response to $3 \mu \mathrm{M}$ VTD (Fig. S4F). The toxin did not show any effects in our $\mathrm{Ca}^{2+}$-imaging assay, as expected. This result illustrates the capability of our assay to distinguish between biotoxins directly affecting the electrical activity of neurons and toxins that exhibit a different, cytotoxic mode of action.
In summary, our findings show the capability of the LUHMES test system to detect biotoxins that affect $\mathrm{Na}_{\mathrm{V}}$ channel activity in an agonistic or antagonistic way. Taken together, the experiments on $\mathrm{P} 2 \mathrm{X}$ receptors and $\mathrm{Na}_{\mathrm{V}}$ channels demonstrated that whole-culture, high throughput $\mathrm{Ca}^{2+}$-imaging is a suitable assay end point to broadly cover various types of functional neurotoxicants.

\section{Electrophysiological characterization and pharmacological modulation of $\mathrm{Na}_{V}$}

Before moving on with exploring further types of potential toxicant targets, we considered it important to provide a basic electrophysiological characterization of the LUHMES cultures. As the cells are derived from a cell line, it was important to confirm that all cells in culture consistently show genuine neuronal electrical properties (as assessed here by the generation of action potentials). A comprehensive investigation of firing behavior $(n=274$ cells) showed that $45 \%$ of cells displayed phasic (Fig. S5A) and 51\% a tonic firing pattern (Fig. S5B). Depolarization failed to induce action potentials in only $4 \%$ of the cells. Such a co-occurrence of phasic and tonic action potential firing behavior has also been described for primary dopaminergic neurons (Grace and Bunney 1984a, b). These findings support our earlier data on few selected cells (Scholz et al. 2011), and provide clear proof for functional expression of voltage-gated ion channels throughout the whole population.

When cells were exposed to depolarizing voltage pulses (voltage clamp recordings), rapid transient inward currents were observed when the membrane potential was raised to levels higher than $-40 \mathrm{mV}$. This was followed by long-lasting outward currents (Fig. 4a, b). The inward currents were blocked by TTX $(1 \mu \mathrm{M})$. Outward currents were inhibited by a combination of TEA ( $10 \mathrm{mM}$ intra- and extracellularly) together with the replacement of $\mathrm{K}^{+}$with $\mathrm{Cs}^{+}$in the intracellular solution (data not shown) to prevent current flow through $\mathrm{K}_{\mathrm{V}}$ channels. Taken together, these data confirmed expression of functional $\mathrm{Na}_{\mathrm{V}}$ and $\mathrm{K}_{\mathrm{V}}$ channels, a key feature of excitable neurons. To further provide a solid background description of the test system, we obtained gene expression data for many channel constituents and other genes involved in neuronal signaling. The distinct neuronal features of the cells were also confirmed here (Fig. S2).

To better understand the functional implication of the expression of different $\mathrm{Na}_{\mathrm{V}}$ channel subtypes, we set out to explore their potential electrophysiological role in LUHMES. Because of the higher throughput than manual patch clamp, we used automated planar patch clamp recordings to obtain detailed biophysical data on the $\mathrm{Na}_{\mathrm{V}}$ channels. All features were in good agreement with data on $\mathrm{Na}_{\mathrm{V}}$ expression systems (Fig. S5C-F) (Cummins et al. 2001; 
McCormack et al. 2013; Oliva et al. 2014; Patel et al. 2016). This coherence also applied to the use dependence of the channels, a feature which can have important toxicological implications (Fig. 4c). Lidocaine was studied here as a wellknown example of a use-dependent blocker for $\mathrm{Na}_{\mathrm{V}}$ channels. It led to significantly different $\mathrm{pIC}_{50}$ values of 3.03 (for the 1st peak of a stimulation sequence) vs 3.57 (10th peak of the sequence, Fig. 4d). The higher potency of lidocaine on the tenth $\mathrm{Na}_{\mathrm{V}}$ current peak indicates a use-dependent mechanism of the inhibition on $\mathrm{Na}_{\mathrm{V}}$ channels as reported previously (Clarkson et al. 1988; Huang et al. 2006; Leffler et al. 2007). The $\mathrm{pIC}_{50}$ values of lidocaine were similar to those obtained for rat hippocampal neurons ( 3.4) (Kaneda et al. 1989).

As $\mathrm{Na}_{\mathrm{V}}$ channel subtypes play an important role in toxicology and pharmacology, we used here TTX as tool to distinguish two major classes potentially expressed on LUHMES. The $\mathrm{pIC}_{50}$ values found here for TTX were in the low $\mathrm{nM}$ range ( 7.2), indicating the presence of TTXsensitive $\mathrm{Na}_{\mathrm{V}}$ channels. To compare these inhibition data to the lidocaine data set, we explored whether TTX effects were use dependent. In contrast to lidocaine, the $\mathrm{pIC}_{50}$ for the first and the tenth pulse were identical for TTX (Fig. 4d).
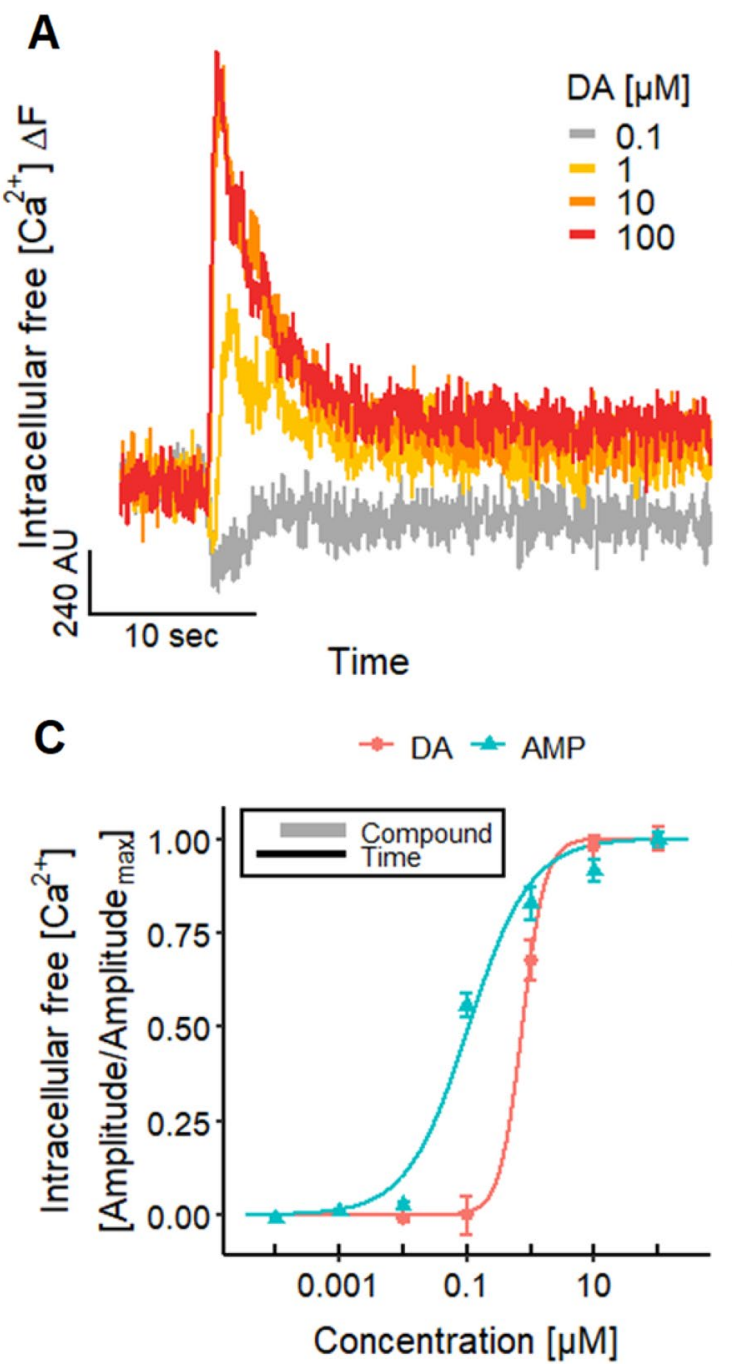

Fig. 5 Altered neuronal signaling by DAT substrates. a, b Traces of $\mathrm{Ca}^{2+}$-imaging experiments illustrating the responses of the LUHMES neurons evoked by different concentrations of a dopamine (DA) and b amphetamine (AMP). c Concentration-response curves for DA and AMP with $\mathrm{pEC}_{50}$ values of $6.13 \pm 0.12$ and $6.98 \pm 0.06$, respectively. Note the treatment scheme (upper left corner), illustrating the experi-

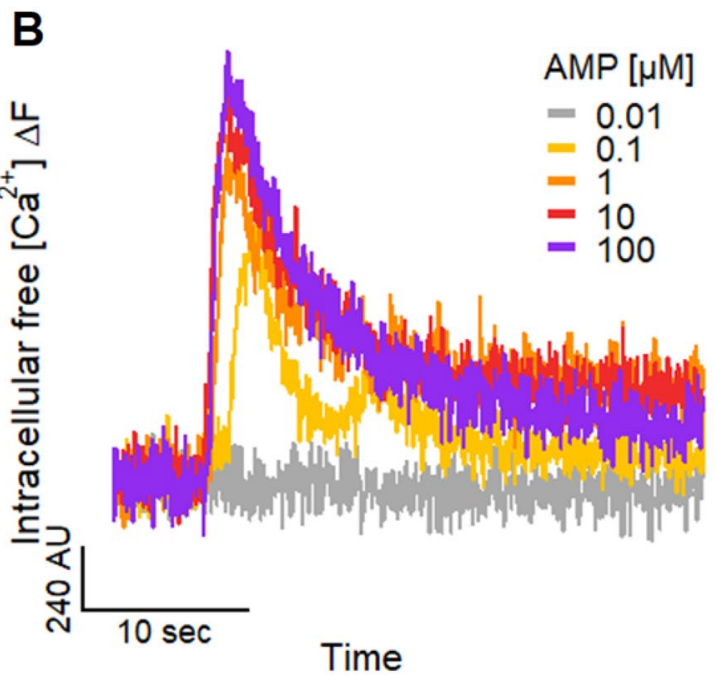

D

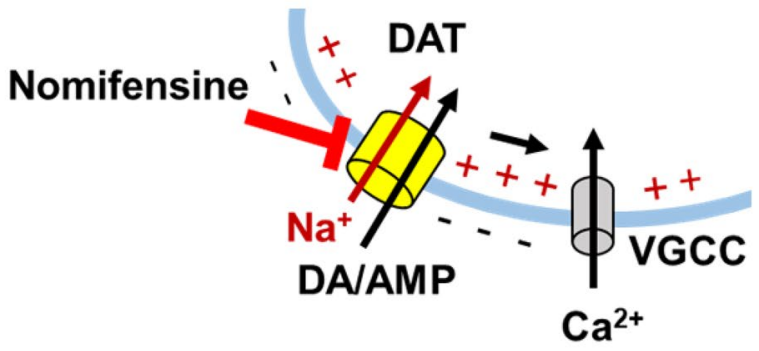

mental design. Detailed data on n numbers are found in table S4. d Schematic illustration of the underlying mechanisms of $\mathrm{Ca}^{2+}$-imaging signals evoked by DA and AMP. The transport of DA and AMP via the DAT into the cell leads to a net influx of one positive charge $\left(\mathrm{Na}^{+}\right)$that can active voltage-gated ion channels, like $\mathrm{Ca}_{\mathrm{V}}$ ion channels. The DAT can be blocked by nomifensine 
Based on these data, the $\mathrm{Na}_{\mathrm{V}}$ subtypes of LUHMES may be $\mathrm{Na}_{\mathrm{V}} 1.1, \mathrm{Na}_{\mathrm{V}} 1.2, \mathrm{Na}_{\mathrm{V}} 1.3, \mathrm{Na}_{\mathrm{V}} 1.4, \mathrm{Na}_{\mathrm{V}} 1.6$ or $\mathrm{Na}_{\mathrm{V}} 1.7$ (all reported to be TTX-sensitive, Ogata and Ohishi 2002; Lee and Ruben 2008; England and de Groot 2009; Zhang et al. 2013). However, the subtypes $\mathrm{Na}_{\mathrm{V}} 1.4$ and $\mathrm{Na}_{\mathrm{V}} 1.7$ are mainly present in skeletal muscle and in the peripheral nervous system, respectively (Ogata and Ohishi 2002; Lee and Ruben 2008; England and de Groot 2009; Zhang et al. 2013). The remaining subtypes $\mathrm{Na}_{\mathrm{V}} 1.1, \mathrm{Na}_{\mathrm{V}} 1.2, \mathrm{Na}_{\mathrm{V}} 1.3$ and $\mathrm{Na}_{\mathrm{V}} 1.6$ are strongly expressed in the CNS (Ogata and Ohishi 2002; Lee and Ruben 2008; England and de Groot 2009; Zhang et al. 2013). To further narrow down $\mathrm{Na}_{\mathrm{V}}$ channel subtypes, the selective $\mathrm{Na}_{\mathrm{V}}$ channel antagonist ICA-121431 was used. It has been shown to exhibit high potency for $\mathrm{Na}_{\mathrm{V}} 1.1$ and $\mathrm{Na}_{\mathrm{V}} 1.3\left(\mathrm{IC}_{50}=0.023 \mu \mathrm{M}\right.$ and $0.013 \mu \mathrm{M}$, respectively), an intermediate potency for $\mathrm{Na}_{\mathrm{V}} 1.2\left(\mathrm{IC}_{50}=0.240 \mu \mathrm{M}\right)$ and low potency for $\mathrm{Na}_{\mathrm{V}} 1.6$ and $\mathrm{Na}_{\mathrm{V}} 1.7\left(\mathrm{IC}_{50}=13 \mu \mathrm{M}\right.$ and $\left.10 \mu \mathrm{M}\right)$, respectively (McCormack et al. 2013). We found a $\mathrm{pIC}_{50}$ value of 6.3, (Fig. 4e, f), characteristic for $\mathrm{Na}_{\mathrm{V}} 1.2$ (McCormack et al. 2013). This implies that the mainly active $\mathrm{Na}_{\mathrm{V}}$ channel subtype in the LUHMES neurons is $\mathrm{Na}_{\mathrm{V}} 1.2$. These findings are consistent with the expression levels of $\mathrm{Na}_{\mathrm{V}}$ channels (Fig. S2). Data on mRNA levels suggest that $\mathrm{Na}_{\mathrm{V}} 1.2$ and $\mathrm{Na}_{\mathrm{V}} 1.9$ show a time-dependent expression, reaching a maximum on $\mathrm{d} 9$. Other channels (e.g., $\mathrm{Na}_{\mathrm{V}} 1.3$ and $\mathrm{Na}_{\mathrm{V}} 1.8$ ) are also expressed on $\mathrm{d} 9$, but do not show the typical developmental up-regulation.

\section{Assessment of agents interfering with the dopamine transporter (DAT)}

As LUHMES are dopaminergic cells, we chose the dopamine transporter (DAT) to exemplify measurements of electrogenic effects of neuronal transporters. This was intended as basis to explore functional neurotoxicity of transporter modulating drugs. To confirm the expression of functional DAT, we examined the uptake of radioactively-labeled DA $\left(\left[{ }^{3} \mathrm{H}\right] \mathrm{DA}\right)$ into LUHMES cells. There was a fast and specific uptake, as expected (Fig. S6). The uptake of $\left[{ }^{3} \mathrm{H}\right]$ DA was significantly reduced by the DAT inhibitors AMP, GBR12935 (Andersen 1987; Rothman et al. 1993), cocaine (Han and Gu 2006; Schmitt et al. 2013) and nomifensine.

The DAT acts as a symporter of dopamine, two $\mathrm{Na}^{+}$and one $\mathrm{Cl}^{-}$ion, and depends on the electro-chemical gradient of the two ions to transport dopamine into the neurons (Harris and Baldessarini 1973; Kuhar and Zarbin 1978; Krueger 1990; Gu et al. 1994; Sonders et al. 1997; Schenk 2002). This transport can lead to a depolarization of the membrane potential and thereby to an activation of voltage-gated ion channels (Sonders et al. 1997; Sitte et al. 1998; Robertson et al. 2009; Cameron et al. 2015). Cameron et al. (2015), showed recently that the activation of the DAT by dopamine (DA) and amphetamine (AMP) leads to the activation of L-type $\mathrm{Ca}_{\mathrm{V}}$ channels.

Measurements of $\mathrm{Ca}^{2+}$ showed that this end point can be used to monitor DAT activity in LUHMES cultures: The addition of DA evoked an increase in $\left[\mathrm{Ca}^{2+}\right]_{\mathrm{i}}$ (Fig. 5a). Furthermore, the psychostimulant drug amphetamine (AMP), which acts as a substrate of the DAT (Sonders et al. 1997;

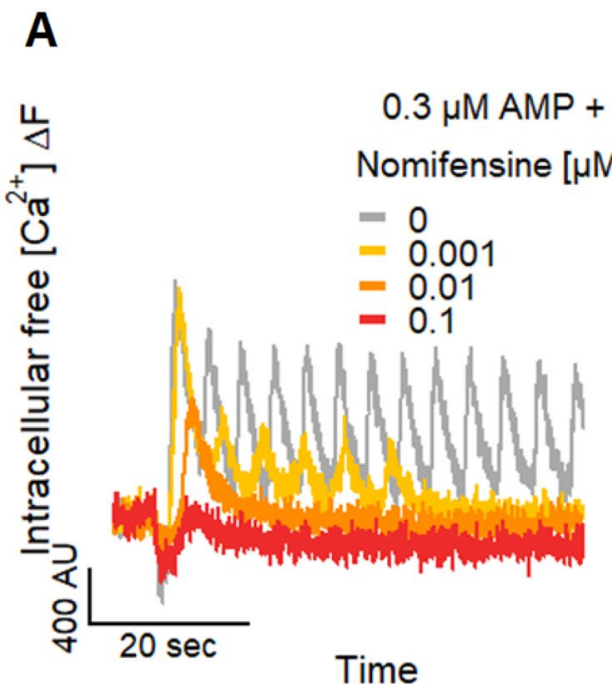

Fig. 6 Altered neuronal signaling by blocking the DAT. a $\mathrm{Ca}^{2+}$-imaging traces of the inhibitory effect of nomifensine on the response of LUHMES neurons to $0.3 \mu \mathrm{M}$ AMP. b The concentration-dependent inhibition by nomifensine resulted in $\mathrm{pIC}_{50}$ values
B $\rightarrow$ DA $[1 \mu \mathrm{M}] \rightarrow$ AMP $[0.3 \mu \mathrm{MM}]$

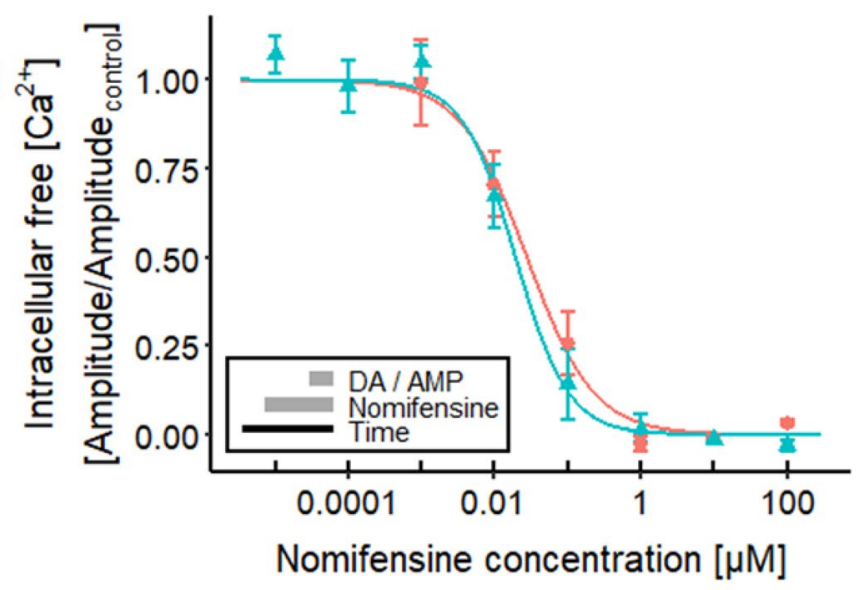

of $7.55 \pm 0.12$ for DA and $7.71 \pm 0.10$ for AMP. Note the treatment scheme (lower left corner), illustrating the experimental design. Detailed data on n numbers are found in table S4 


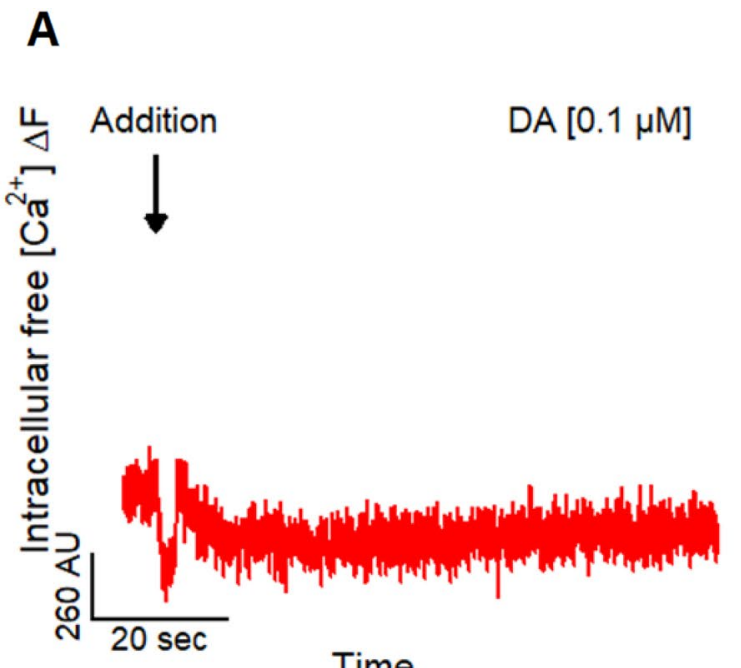

Time
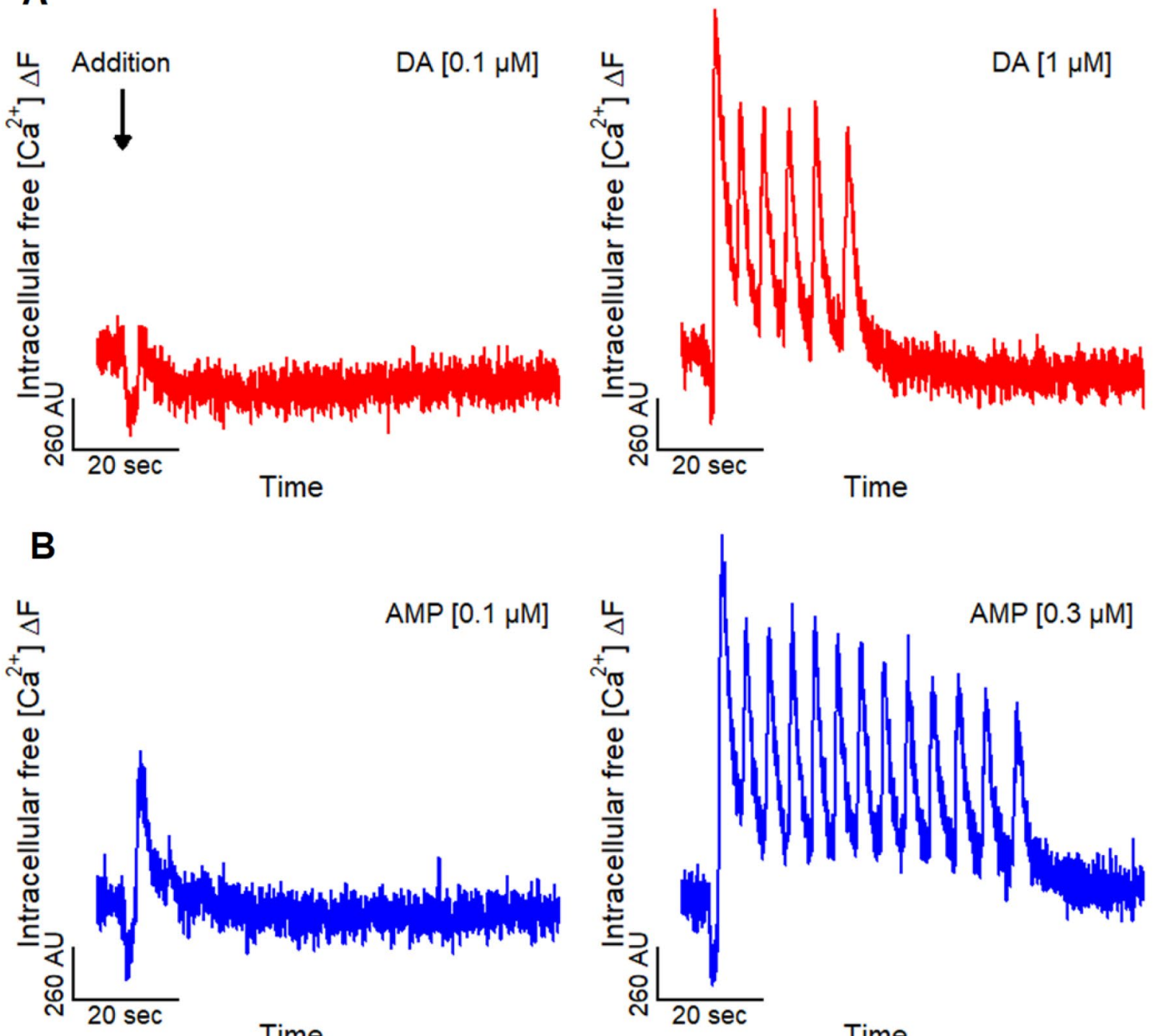

Time
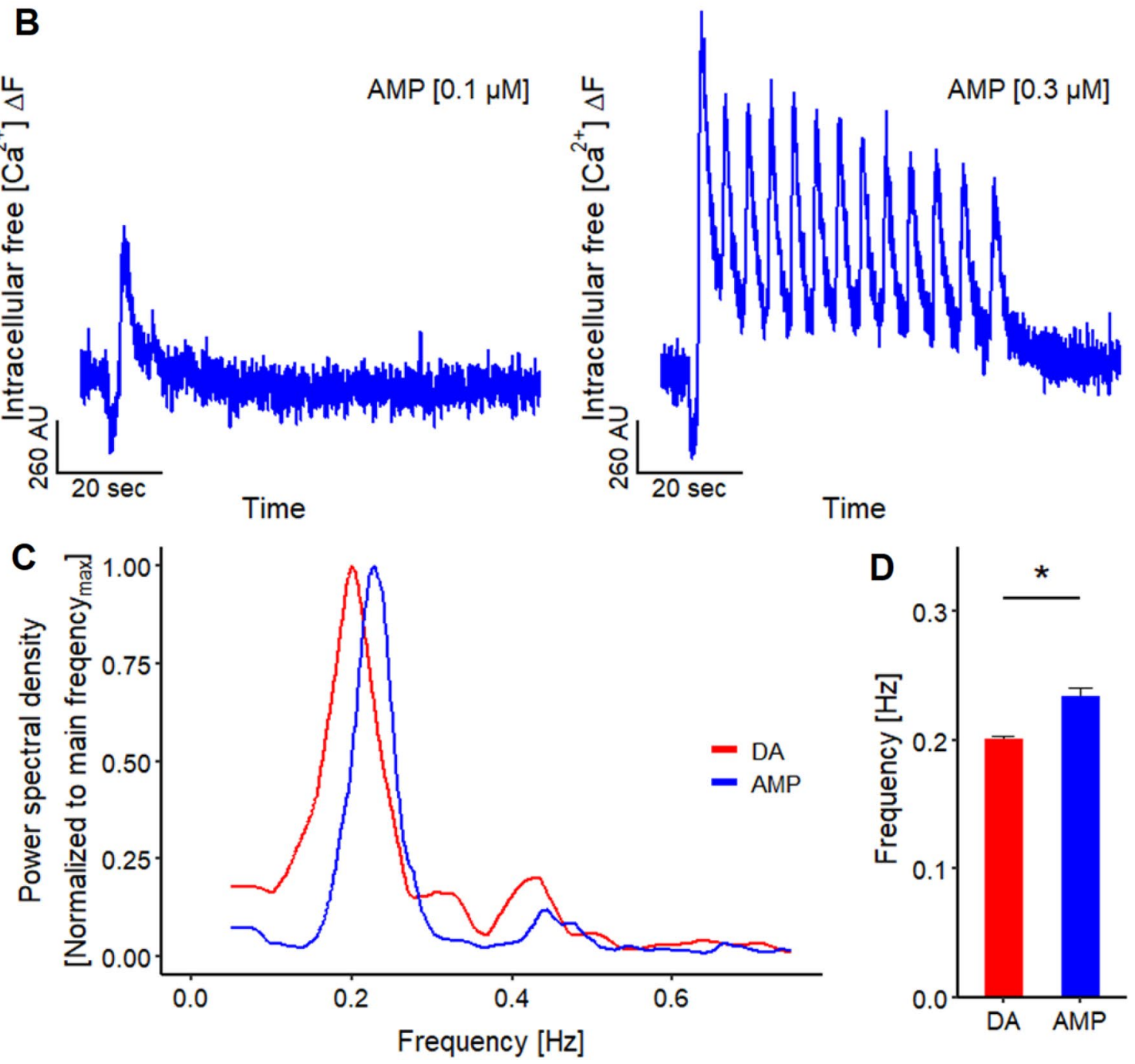
4Fig. 7 Oscillation of $\mathrm{Ca}^{2+}$-imaging signal. a Traces of $\mathrm{Ca}^{2+}$-imaging signals of the application of 0.1 and $1 \mu \mathrm{M}$ DA. The latter concentration induced in $61.6 \%(n=125)$ of the recordings oscillations of the $\mathrm{Ca}^{2+}$-imaging signal. b Exemplary traces of the addition of 0.1 and $0.3 \mu \mathrm{M}$ AMP. Oscillations of the $\mathrm{Ca}^{2+}$-imaging signal were induced by the application of $0.3 \mu \mathrm{M}$ AMP in $94.0 \%(n=50)$ of the recordings. c Periodogram based on the mean results of FFT analysis of the oscillations induced by $1 \mu \mathrm{M}$ DA $(n=6)$ and $0.3 \mu \mathrm{M}$ AMP $(n=10)$ highlighting a main oscillation frequency. d Main oscillation frequency for $1 \mu \mathrm{M}$ DA and $0.3 \mu \mathrm{M}$ AMP are $0.201 \pm 0.002 \mathrm{~Hz}(n=6)$ and $0.234 \pm 0.007 \mathrm{~Hz}(n=10)$, respectively. Statistical significance was determined between DA and AMP (*, significant)

Sitte et al. 1998; Jones et al. 1998; Fleckenstein et al. 2007; Robertson et al. 2009; Schmitt et al. 2013; Siciliano et al. 2014; Cameron et al. 2015), induced also signals in $\mathrm{Ca}^{2+}$-imaging experiments (Fig. 5b) (Cameron et al. 2015). The $\mathrm{pEC}_{50}$ of 6.1 and 7.0 for DA and AMP, respectively (Fig. 5c), are in accordance with published findings (Cameron et al. 2015).

To make use of the fact that measurements of $\left[\mathrm{Ca}^{2+}\right]_{i}$ can give very exact information on compounds affecting the DAT (Fig. 5d), we explored this approach for characterization of antagonists. The DAT blocker nomifensine (Andersen 1989; Krueger 1990; Sulzer et al. 1995) inhibited the responses evoked by DA and AMP (Fig. 6a) with a $\mathrm{pIC}_{50}$ value of 7.6-7.7 (Fig. 6b). This is similar to data on the uptake of radioactively labeled DA in rat synaptosomes (Randrup and Bræstrup 1977).

These results demonstrate the usability of our LUHMES cell-based test system for the assessment of substanceinduced changes in DAT activity. The use of high-throughput $\mathrm{Ca}^{2+}$-imaging allows the direct detection of DAT-mediated signal changes without requiring special reagents (radioactive labeling to measure $\left[{ }^{3} \mathrm{H}\right] \mathrm{DA}$ uptake).

\section{$\mathrm{Ca}^{2+}$-oscillations as indicator of coupled neuronal networks}

Addition of DA (Fig. 7a) and AMP (Fig. 7b) triggered not only an increase of $\left[\mathrm{Ca}^{2+}\right]_{\mathrm{i}}$, but also prominent and long-lasting oscillations of the $\mathrm{Ca}^{2+}$-imaging signal. This observation is insofar remarkable, as the $\left[\mathrm{Ca}^{2+}\right]_{i}$-signal was derived from thousands of cells at the same time, and from an area having a diameter of $>2000 \mu \mathrm{m}$ (for comparison: LUHMES cell bodies are about $20 \mu \mathrm{m}$ wide). As non-coordinated oscillations of individual cells would cancel out under our measurement conditions (recording of the average signal of all cells), the measurable oscillations indicate that all cells change $\left[\mathrm{Ca}^{2+}\right]_{\mathrm{i}}$ in a synchronized way, and that LUHMES cultures must therefore form a functionally coupled network.

We explored how consistent this phenomenon occurred across several wells and cell differentiations: in $62 \%$ $(n=125)$ of cases, DA $(1 \mu \mathrm{M})$ triggered oscillations. When AMP $(0.3 \mu \mathrm{M})$ was used, oscillations were observed in 48 of 50 experiments. The oscillation frequency was consistent throughout the experiments in a range of $0.2-0.23 \mathrm{~Hz}$ (Fig. 7c, d). This means that the entire culture in a well increased the average $\left[\mathrm{Ca}^{2+}\right]_{\mathrm{i}}$ about every $5 \mathrm{~s}$ in a coordinated way. In summary, these findings suggest that whole culture measurements of $\left[\mathrm{Ca}^{2+}\right]_{i}$ allow assessment of neuronal network properties. An example of a drug triggering network oscillations is given here with AMP.

\section{Modulation of $\left[\mathrm{Ca}^{2+}\right]_{\mathrm{i}}$ oscillations in functionally coupled neuronal cultures}

To test the hypothesis that DAT activity is required for the oscillations, we used the DAT blocker nomifensine. The oscillations induced by AMP and DA were indeed blocked by this drug (Fig. 6a). Nomifensine thus exemplifies possible modes of action of drugs that dampen or break network synchronization. However, it was important to test whether oscillations driven by the DAT may also be modified by drugs with other neuronal targets. We therefore asked which types of channels may be involved in ensuring coordinated oscillatory activity in LUHMES cultures, and whether drugs interfering with such channels would affect network oscillations as potential neurofunctional end point.

First, we examined the involvement of $\mathrm{Na}_{\mathrm{V}}$ channels in $\mathrm{Ca}^{2+}$-oscillations by using TTX to block action potential generation and propagation along the neurites. The signal amplitudes induced by DA $(1 \mu \mathrm{M})$ and AMP $(0.3 \mu \mathrm{M})$ were significantly reduced to 69 and $21 \%$, respectively (Fig. 8a-d). Although these effects indicate a contribution of $\mathrm{Na}_{\mathrm{V}}$ channels, they also suggest that there are additional components mandatory for the observed oscillations. We therefore examined the participation of L-type $\mathrm{Ca}_{\mathrm{V}}$ channels in $\mathrm{Ca}^{2+}$-oscillations: the selective L-type $\mathrm{Ca}_{\mathrm{V}}$ channel antagonist nifedipine (Helton et al. 2005) reduced the oscillation amplitude to $70 \%$ for DA and to $51 \%$ for AMP. These findings suggest that functional L-type $\mathrm{Ca}_{\mathrm{V}}$ channels are involved in $\mathrm{Ca}^{2+}$-oscillations. Their presence is in line with the expression levels of L-type $\mathrm{Ca}_{\mathrm{V}}$ channel mRNA (Fig. S2), indicating a high expression of $\mathrm{Ca}_{\mathrm{V}} 1.2$. As the presence of functional T-type $\mathrm{Ca}_{\mathrm{V}}$ channels is supported by high mRNA levels of $\mathrm{Ca}_{\mathrm{v}} 3.2$ (Fig. S2), we investigated the impact of T-type $\mathrm{Ca}_{\mathrm{V}}$ channels on the DA/AMP induced oscillations: the selective $\mathrm{T}$-type $\mathrm{Ca}_{\mathrm{V}}$ channel blocker NNC 55-0396 (NNC, Huang et al. 2004) caused a strong reduction of the amplitude to $2-3 \%$ (>95\% inhibition) (Fig. 8a-d). This indicates a major contribution of T-type $\mathrm{Ca}_{\mathrm{V}}$ channels in $\mathrm{Ca}^{2+}$-oscillations.

One may ask why T-type $\mathrm{Ca}_{\mathrm{V}}$ channels take such an important role here (Fig. 8e): These $\mathrm{Ca}_{\mathrm{V}}$ channels have a lower activation threshold compared to $\mathrm{L}$-type $\mathrm{Ca}_{\mathrm{V}}$ channels (Helton et al. 2005; Lieb et al. 2014). This higher voltage sensitivity enables a stronger electrical coupling with the 

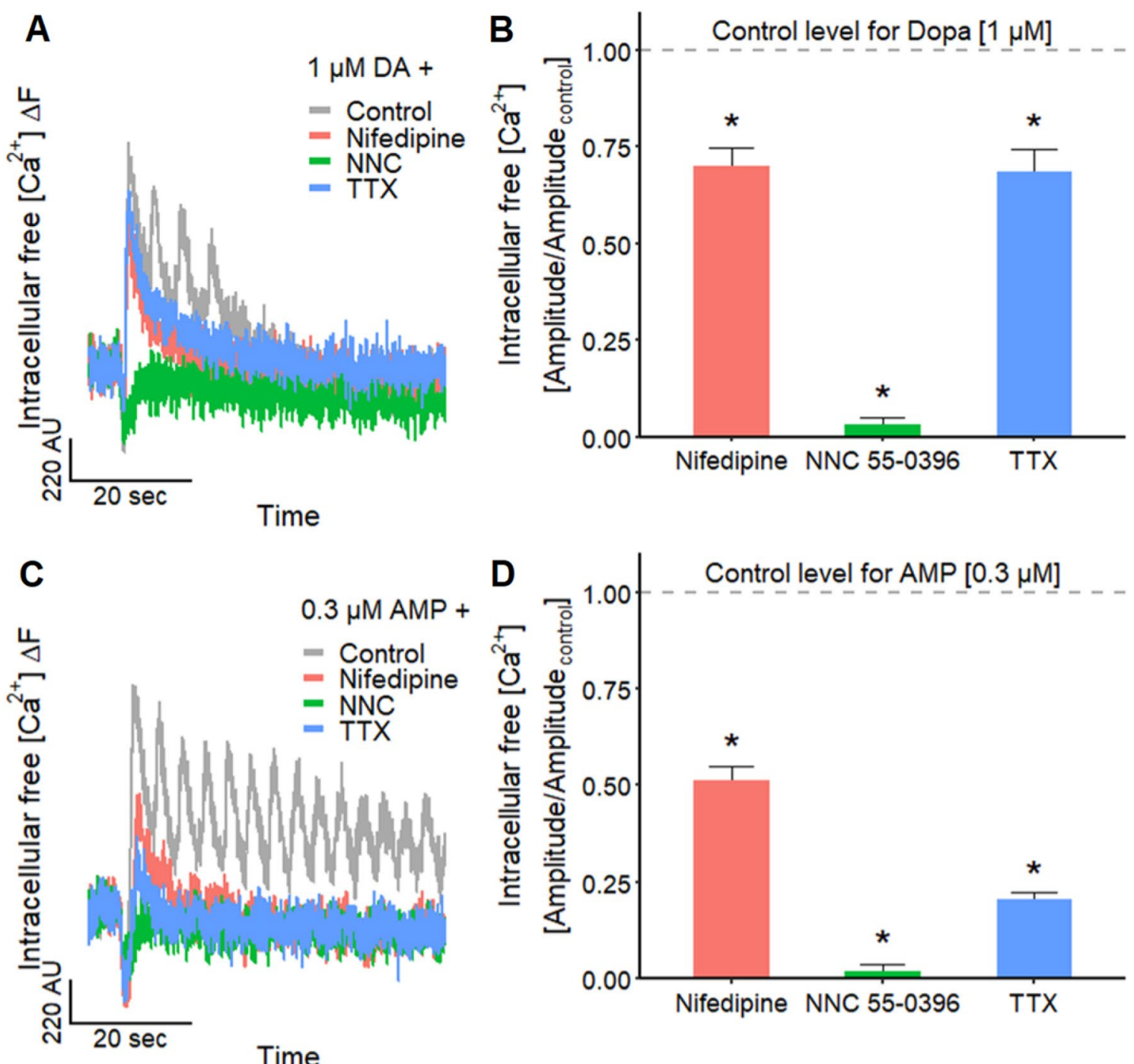

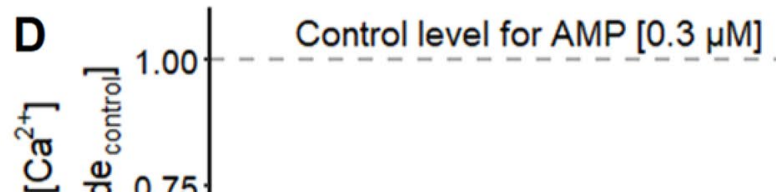

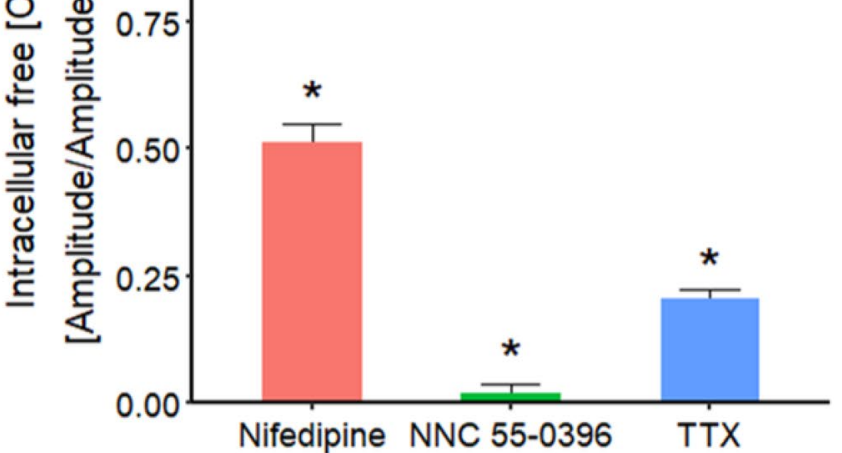

Time

E

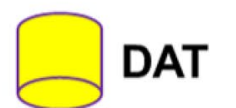

T-type $\mathrm{Ca}_{\mathrm{V}}$

$\bigcap \mathbf{N a} a_{v}$

L-type $\mathrm{Ca}_{\mathrm{V}}$

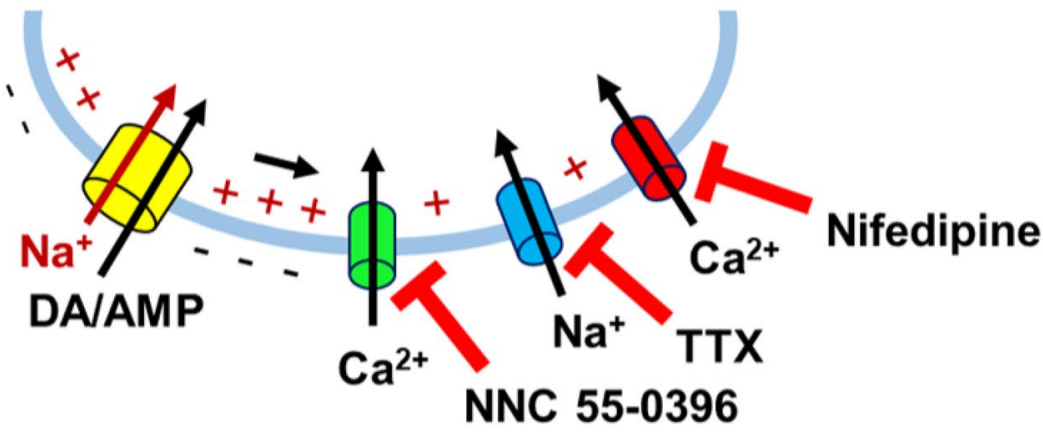


४Fig. 8 Substance-induced modulation of $\mathrm{Ca}^{2+}$-imaging signal oscillations. a Traces of a $\mathrm{Ca}^{2+}$-imaging experiment with LUHMES cells displaying the responses triggered by $1 \mu \mathrm{M}$ DA during control and in the presence of $10 \mu \mathrm{M}$ nifedipine ( $\mathrm{L}$-type $\mathrm{Ca}_{\mathrm{V}}$ channel inhibitor), $30 \mu \mathrm{M}$ NNC 55-0396 (NNC; T-type $\mathrm{Ca}_{\mathrm{V}}$ channel inhibitor) and TTX $(1 \mu \mathrm{M})$. Note the $\mathrm{Ca}^{2+}$-imaging signal oscillations during control. b Corresponding mean inhibitory effects of the three antagonists on the signal evoked by $1 \mu \mathrm{M}$ DA. The amplitude was reduced compared to control $(n=5)$ to $70.2 \pm 0.05 \%$ by nifedipine $(n=6)$, to $3.0 \pm 0.02 \%$ by NNC $55-0396(n=6)$ and to $68.6 \pm 0.06 \%$ by TTX $(n=6)$. Statistical significance was determined against negative control recordings (*, significant). c $\mathrm{Ca}^{2+}$-imaging traces showing the effect of $10 \mu \mathrm{M}$ nifedipine, $30 \mu \mathrm{M}$ NNC 55-0396 (NNC) and $1 \mu \mathrm{M}$ TTX on the responses of the LUHMES neurons stimulated by the addition of $0.3 \mu \mathrm{M}$ AMP. Note the $\mathrm{Ca}^{2+}$-imaging signal oscillations during control. d Mean inhibitory effects of the antagonists on the response triggered by $0.3 \mu \mathrm{M}$ AMP. The amplitude was reduced compared to control $(n=6)$ to $51.4 \pm 0.03 \%$ by nifedipine $(n=6)$, to $2.1 \pm 0.02 \%$ by NNC $55-0396(n=5)$ and to $20.5 \pm 0.02 \%$ by TTX $(n=6)$. Statistical significance was determined against negative control recordings (*, significant). e Schematic illustration of the results and the underlying context. The transport of DA and AMP by the DAT results in a net influx of one positive charge $\left(\mathrm{Na}^{+}\right)$into the cell which can activate voltage-gated ion channels via a depolarization of the membrane potential (Fig. 5)

DAT (Cameron et al. 2015), but it may also have important pathophysiological (e.g., epilepsy (Huc et al. 2009; Cain and Snutch 2013)) and toxicological implications.

In summary, this final set of experiments showed that LUHMES cultures, assessed by whole-well $\mathrm{Ca}^{2+}$-imaging as an end point not only can be used to investigate modulations of ion channels, neurotransmitter receptors, and transporters that affect individual neurons, but also for identification of chemicals that alter synchronous activity in this test system.

\section{Conclusions and outlook}

LUHMES have in the past been used as toxicity test system with biochemical and morphological end points (Scholz et al. 2011; Smirnova et al. 2016; Delp et al. 2018b, 2019; Brüll et al. 2020). To the best of our knowledge, we provide here for the first time an extensive overview of neurophysiological changes triggered by external chemicals in LUHMES neurons. We show a broad panel of such responses to exemplify the functioning and performance of LUHMES as test system of functional neurotoxicity. Some of the results yield further neurobiological characterization of the test system.

For instance, our results indicate the functional expression of $\mathrm{P} 2 \mathrm{X} 3$ receptors, as demonstrated by the inhibitory effect of A-317491 on the response evoked by $\alpha, \beta$-meATP. We also illustrated the high reproducibility of the differentiation of LUHMES neurons by the low standard deviation of 0.16 of five $\mathrm{pEC}_{50}$ values (mean of 7.52) determined for the responses of five differentiations to $\alpha, \beta$-meATP. A use case was given by the characterization of suramin and by showing how the system can be used to provide exact quantitative data on agonist and antagonist potencies and specificities. In the future, the identification of side effects of antiepileptic and anti-inflammatory drugs addressing purinergic receptors could be of interest, due to their wide distribution in the nervous system (Burnstock and Verkhratsky 2012; Di Virgilio and Vuerich 2015; Riquelme et al. 2020).

In a further step, we showed that high-throughput $\mathrm{Ca}^{2+}$ assays can substitute patch clamp for many applications, and provide a central toxicological platform to investigate diverse neurofunctional modulators/toxicants. This method enables the utilization of adherent cells in an intact neuronal network compared to automated patch clamp, where cells need to be detached. This assay served, e.g., as a useful tool for the detection of marine neurotoxins such as TTX, STX and CTX. It may be used in the future also for, e.g., cyanobacterial toxins, like kalkitoxin (LePage et al. 2005). The possibility of examining use-dependent effects on this $\mathrm{Na}_{\mathrm{V}}$ channel is also meaningful for the research of anticonvulsants, like phenytoin (Goldenberg 2010; Brodie 2017), and the detection of side effects of local anesthetics or pyrethroids on CNS $\mathrm{Na}_{\mathrm{V}}$ channels (Groban 2003; Mather et al. 2005; Neal et al. 2010; Cao et al. 2011; Casida and Durkin 2013).

Scholz et al. (2011) mentioned the presence of TTX-sensitive $\mathrm{Na}_{\mathrm{V}}$ channels in this cell model. We went further by identifying $\mathrm{Na}_{\mathrm{V}} 1.2$ as the major functionally active sodium channel (Fig. 4f). By establishing a procedure to utilize the LUHMES neurons in automated patch clamp, we overcame the low throughput of manual patch clamp.

A major outcome of our study, besides the broad test system description as necessary basis for further work, was the demonstration that LUHMES neurons are functionally coupled over long distances (entire well). The finding of oscillations of activity was very clear for different stimuli such as DA, AMP and CTX, and we provided a description of the robustness of the phenomenon. A thorough investigation of the underlying biology was out of the scope of this study, but it is an important goal for the future. To substantiate our findings, and to ensure they are not strange random observations, we provided some mechanistic links: DAT and T-type $\mathrm{Ca}_{\mathrm{V}}$ were found to be major players in such culture $\left[\mathrm{Ca}^{2+}\right]_{\mathrm{i}}$ oscillations, and also $\mathrm{Na}_{\mathrm{V}}$ contributed to them. Potential applications for this assay could be the identification of all agents that disturb neuronal network functions, such as antipsychotics, seizurogenic substances and antiepileptic drugs that do not solely affect the GABA-glutamate system.

In summary, we highlighted the suitability of LUHMES neuronal cultures as powerful tool for high-throughput neuronal toxicity screening using industry-applicable automated patch clamp and $\mathrm{Ca}^{2+}$-imaging. Furthermore, we revealed 
the presence of several meaningful targets on the LUHMES neurons for the assessment of neurotoxicity and exemplified this in several case studies. In future studies, it would be worthwhile investigating the effects of the tested neurotoxicants on 3D models and co-culture systems with astrocytes (Brüll et al. 2020).

Acknowledgements This work was supported by the BMBF, the InViTe PhD program from the Baden-Wuerttemberg Ministry for Science, Research and Art (MWK Baden-Württemberg), EFSA, the DK-EPA (MST-667-00205), and the University of Konstanz. It has received funding from the European Union's Horizon 2020 research and innovation programme under grant agreements No. 681002 (EUToxRisk) and No. 825759 (ENDpoiNTs). The authors would like to thank Richard Lewis (University of Queensland) and Daniel Dietrich (University of Konstanz) for providing the pacific ciguatoxin (pCTX) and Daniel Legler (University of Konstanz) for supplying the suramin.

Author contributions DL: conceived of or designed the study, performed research, analyzed data and wrote the paper. JS, IS, SK: performed research and analyzed data. TD, CM: conceived of or designed the study, contributed new methods or models and analyzed data. MB, AÜ: performed research, analyzed data and wrote the paper. ML, UK: conceived of or designed the study and wrote the paper.

Funding Open Access funding enabled and organized by Projekt DEAL.

\section{Compliance with ethical standards}

Conflict of interest The authors declare no conflict of interest.

Open Access This article is licensed under a Creative Commons Attribution 4.0 International License, which permits use, sharing, adaptation, distribution and reproduction in any medium or format, as long as you give appropriate credit to the original author(s) and the source, provide a link to the Creative Commons licence, and indicate if changes were made. The images or other third party material in this article are included in the article's Creative Commons licence, unless indicated otherwise in a credit line to the material. If material is not included in the article's Creative Commons licence and your intended use is not permitted by statutory regulation or exceeds the permitted use, you will need to obtain permission directly from the copyright holder. To view a copy of this licence, visit http://creativecommons.org/licenses/by/4.0/.

\section{References}

Abbracchio MP, Burnstock G (1994) Purinoceptors: are there families of P2X and P2Y purinoceptors? Pharmacol Ther 64:445-475. https://doi.org/10.1016/0163-7258(94)00048-4

Abbracchio MP, Burnstock G, Boeynaems J-M et al (2006) International Union of Pharmacology LVIII: update on the P2Y G protein-coupled nucleotide receptors: from molecular mechanisms and pathophysiology to therapy. Pharmacol Rev 58:281-341. https://doi.org/10.1124/pr.58.3.3

Alkadhi KA, Tian L-M (1996) Veratridine-enhanced persistent sodium current induces bursting in CA1 pyramidal neurons. Neuroscience 71:625-632. https://doi.org/10.1016/0306-4522(95)00488-2

Alloisio S, Nobile M, Novellino A (2015) Multiparametric characterisation of neuronal network activity for in vitro agrochemical neurotoxicity assessment. NeuroToxicology 48:152-165. https:// doi.org/10.1016/j.neuro.2015.03.013

Amadio S, Montilli C, Picconi B et al (2007) Mapping P2X and P2Y receptor proteins in striatum and substantia nigra: an immunohistological study. Purinergic Signal 3:389-398. https://doi. org/10.1007/s11302-007-9069-8

Andersen PH (1987) Biochemical and pharmacological characterization of [3H]GBR 12935 binding in vitro to rat striatal membranes: labeling of the dopamine uptake complex. J Neurochem 48:1887-1896. https://doi.org/10.1111/j.1471-4159.1987.tb057 52.x

Andersen PH (1989) The dopamine uptake inhibitor GBR 12909: selectivity and molecular mechanism of action. Eur J Pharmacol 166:493-504. https://doi.org/10.1016/0014-2999(89)90363-4

Anwar M, Turner M, Farrell N et al (2018) Hikers poisoned: Veratrum steroidal alkaloid toxicity following ingestion of foraged Veratrum parviflorum. Clin Toxicol 56:841-845. https://doi. org/10.1080/15563650.2018.1442007

Attali D (2020) shinyjs: easily improve the user experience of your shiny apps in seconds. R package version 1.1. https://CRAN.Rproject.org/package $=$ shinyjs

Bache SM, Wickham H (2014) magrittr: a forward-pipe operator for R. R package version 1.5. https://CRAN.R-project.org/packa ge=magrittr

Bader BM, Steder A, Klein AB et al (2017) Functional characterization of GABAA receptor-mediated modulation of cortical neuron network activity in microelectrode array recordings. PLoS ONE 12:e0186147. https://doi.org/10.1371/journal.pone.0186147

Barbosa DJ, Capela JP, de Lourdes BM, Carvalho F (2015) In vitro models for neurotoxicology research. Toxicol Res 4:801-842. https://doi.org/10.1039/c4tx00043a

Bengtsson H (2020) matrixStats: functions that apply to rows and columns of matrices (and to vectors). R package version 0.56.0. https://CRAN.R-project.org/package=matrixStats

Bianchi BR, Lynch KJ, Touma E et al (1999) Pharmacological characterization of recombinant human and rat $\mathrm{P} 2 \mathrm{X}$ receptor subtypes. Eur J Pharmacol 376:127-138. https://doi.org/10.1016/S0014 -2999(99)00350-7

Bidard JN, Vijverberg HP, Frelin C et al (1984) Ciguatoxin is a novel type of $\mathrm{Na}^{+}$channel toxin. J Biol Chem 259:8353-8357

Birinyi-Strachan LC, Gunning SJ, Lewis RJ, Nicholson GM (2005) Block of voltage-gated potassium channels by Pacific ciguatoxin-1 contributes to increased neuronal excitability in rat sensory neurons. Toxicol Appl Pharmacol 204:175-186. https://doi. org/10.1016/j.taap.2004.08.020

Bradley JA, Luithardt HH, Metea MR, Strock CJ (2018) In vitro screening for seizure liability using microelectrode array technology. Toxicol Sci. https://doi.org/10.1093/toxsci/kfy029

Bravery CA (2015) Do human leukocyte antigen-typed cellular therapeutics based on induced pluripotent stem cells make commercial sense? Stem Cells Dev 24:1-10. https://doi.org/10.1089/ scd.2014.0136

Brodie MJ (2017) Sodium channel blockers in the treatment of epilepsy. CNS Drugs 31:527-534. https://doi.org/10.1007/s4026 3-017-0441-0

Brownjohn PW, Smith J, Portelius E et al (2017) Phenotypic screening identifies modulators of amyloid precursor protein processing in human stem cell models of Alzheimer's disease. Stem Cell Rep 8:870-882. https://doi.org/10.1016/j.stemcr.2017.02.006

Brüll M, Spreng A-S, Gutbier S et al (2020) Incorporation of stem cellderived astrocytes into neuronal organoids to allow neuro-glial interactions in toxicological studies. ALTEX Altern Anim Exp. https://doi.org/10.14573/altex.1911111

Burgard EC, Niforatos W, van Biesen T et al (2000) Competitive antagonism of recombinant $\mathrm{P} 2 \mathrm{X} 2 / 3$ receptors by 
2',3'-O-(2,4,6-trinitrophenyl) adenosine 5'-triphosphate (TNPATP). Mol Pharmacol 58:1502-1510. https://doi.org/10.1124/ mol.58.6.1502

Burnstock G, Kennedy C (1985) Is there a basis for distinguishing two types of P2-purinoceptor? Gen Pharmacol Vasc Syst 16:433440. https://doi.org/10.1016/0306-3623(85)90001-1

Burnstock G, Verkhratsky A (2012) Purinergic signalling in the central nervous system. Purinergic signalling and the nervous system. Springer, Berlin, pp 433-581

Cain SM, Snutch TP (2013) T-type calcium channels in burst-firing, network synchrony, and epilepsy. Biochim Biophys Acta BBA Biomembr 1828:1572-1578. https://doi.org/10.1016/j.bbame m.2012.07.028

Cameron KN, Solis E, Ruchala I et al (2015) Amphetamine activates calcium channels through dopamine transporter-mediated depolarization. Cell Calcium 58:457-466. https://doi.org/10.1016/j. ceca.2015.06.013

Campos A, Vasconcelos V (2010) Molecular mechanisms of microcystin toxicity in animal cells. Int J Mol Sci 11:268-287. https://doi. org/10.3390/ijms11010268

Cao Z, Shafer TJ, Murray TF (2011) Mechanisms of pyrethroid insecticide-induced stimulation of calcium influx in neocortical neurons. J Pharmacol Exp Ther 336:197-205. https://doi. org/10.1124/jpet.110.171850

Casida JE, Durkin KA (2013) Neuroactive insecticides: targets, selectivity, resistance, and secondary effects. Annu Rev Entomol 58:99-117. https://doi.org/10.1146/annurev-ento-12081 $1-153645$

Catterall WA (1992) Cellular and molecular biology of voltagegated sodium channels. Physiol Rev 72:S15-S48. https://doi. org/10.1152/physrev.1992.72.suppl_4.S15

Chang W, Cheng J, Allaire J et al (2020) shiny: web application framework for R. R package version 1.4.0.2. https://CRAN.Rproject.org/package $=$ shiny

Cheng J (2018) miniUI: shiny UI widgets for small screens. R package version 0.1.1.1. https://CRAN.R-project.org/packa ge $=$ miniUI

Cheng X, Dib-Hajj SD, Tyrrell L et al (2011) Deletion mutation of sodium channel $\mathrm{Na}_{\mathrm{V}} 1.7$ in inherited erythromelalgia: enhanced slow inactivation modulates dorsal root ganglion neuron hyperexcitability. Brain 134:1972-1986. https://doi.org/10.1093/brain /awr143

Clarkson CW, Follmer CH, Ten Eick RE et al (1988) Evidence for two components of sodium channel block by lidocaine in isolated cardiac myocytes. Circ Res 63:869-878. https://doi.org/10.1161/01. RES.63.5.869

Coddou C, Yan Z, Obsil T et al (2011) Activation and regulation of purinergic P2X receptor channels. Pharmacol Rev 63:641-683. https://doi.org/10.1124/pr.110.003129

Communi D, Robaye B, Boeynaems J-M (1999) Pharmacological characterization of the human $\mathrm{P} 2 \mathrm{Y} 11$ receptor. Br J Pharmacol 128:1199-1206. https://doi.org/10.1038/sj.bjp.0702909

Cummins TR, Aglieco F, Renganathan $\mathrm{M}$ et al (2001) $\mathrm{Na}_{\mathrm{V}} 1.3$ sodium channels: rapid repriming and slow closed-state inactivation display quantitative differences after expression in a mammalian cell line and in spinal sensory neurons. J Neurosci 21:5952-5961. https://doi.org/10.1523/JNEUROSCI.21-16-05952.2001

Danker T (2018) ephys2: read, analyze and plot HEKA patchmaster files. R package version 0.12 .0 . https://github.com/tdanker/ephys 2

Deeds J, Landsberg J, Etheridge S et al (2008) Non-traditional vectors for paralytic shellfish poisoning. Mar Drugs 6:308-348. https:// doi.org/10.3390/md6020308

Delp J, Gutbier S, Cerff M et al (2018) Stage-specific metabolic features of differentiating neurons: implications for toxicant sensitivity. Toxicol Appl Pharmacol 354:64-80. https://doi. org/10.1016/j.taap.2017.12.013

Delp J, Gutbier S, Klima S et al (2018) A high-throughput approach to identify specific neurotoxicants/developmental toxicants in human neuronal cell function assays. Altex 35:235-253. https:// doi.org/10.14573/altex.1712182

Delp J, Funke M, Rudolf F et al (2019) Development of a neurotoxicity assay that is tuned to detect mitochondrial toxicants. Arch Toxicol 93:1585-1608. https://doi.org/10.1007/s00204-019-02473-y

Di Virgilio F, Vuerich M (2015) Purinergic signaling in the immune system. Auton Neurosci 191:117-123. https://doi.org/10.1016/j. autneu.2015.04.011

Dickey RW, Plakas SM (2010) Ciguatera: a public health perspective. Toxicon 56:123-136. https://doi.org/10.1016/j.toxic on.2009.09.008

Durán-Riveroll L, Cembella A (2017) Guanidinium toxins and their interactions with voltage-gated sodium ion channels. Mar Drugs 15:303. https://doi.org/10.3390/md15100303

Edwards SM (2019) lemon: freshing up your "ggplot2" plots. R package version 0.4.3. https://CRAN.R-project.org/package=lemon

England S, de Groot MJ (2009) Subtype-selective targeting of voltagegated sodium channels. Br J Pharmacol 158:1413-1425. https:// doi.org/10.1111/j.1476-5381.2009.00437.x

Engle SJ, Blaha L, Kleiman RJ (2018) Best practices for translational disease modeling using human iPSC-derived neurons. Neuron 100:783-797. https://doi.org/10.1016/j.neuron.2018.10.033

Fleckenstein AE, Volz TJ, Riddle EL et al (2007) New insights into the mechanism of action of amphetamines. Annu Rev Pharmacol Toxicol 47:681-698. https://doi.org/10.1146/annurev.pharm tox.47.120505.105140

Forsby A, Bal-Price AK, Camins A et al (2009) Neuronal in vitro models for the estimation of acute systemic toxicity. Toxicol In Vitro 23:1564-1569. https://doi.org/10.1016/j.tiv.2009.07.017

Gaillard Y, Pepin G (2001) LC-EI-MS determination of veratridine and cevadine in two fatal cases of veratrum album poisoning. J Anal Toxicol 25:481-485. https://doi.org/10.1093/jat/25.6.481

Garcia-Guzman M, Stühmer W, Soto F (1997) Molecular characterization and pharmacological properties of the human $\mathrm{P} 2 \mathrm{X} 3$ purinoceptor. Mol Brain Res 47:59-66. https://doi.org/10.1016/S0169 $-328 X(97) 00036-3$

Gerhardt E, Kügler S, Leist M et al (2001) Cascade of caspase activation in potassium-deprived cerebellar granule neurons: targets for treatment with peptide and protein inhibitors of apoptosis. Mol Cell Neurosci 17:717-731. https://doi.org/10.1006/ mene.2001.0962

Gever JR, Cockayne DA, Dillon MP et al (2006) Pharmacology of P2X channels. Pflüg Arch Eur J Physiol 452:513-537. https:// doi.org/10.1007/s00424-006-0070-9

Giardina C, Cutroneo PM, Mocciaro E et al (2018) Adverse Drug reactions in hospitalized patients: results of the FORWARD (Facilitation of Reporting in Hospital Ward) study. Front Pharmacol. https://doi.org/10.3389/fphar.2018.00350

Goldenberg MM (2010) Overview of drugs used for epilepsy and seizures. Pharm Ther 35:392-415

Grace AA, Bunney BS (1984a) The control of firing pattern in nigral dopamine neurons: burst firing. J Neurosci 4:2877-2890. https ://doi.org/10.1523/JNEUROSCI.04-11-02877.1984

Grace AA, Bunney BS (1984b) The control of firing pattern in nigral dopamine neurons: single spike firing. J Neurosci 4:2866-2876. https://doi.org/10.1523/JNEUROSCI.04-11-02866.1984

Groban L (2003) Central nervous system and cardiac effects from long-acting amide local anesthetic toxicity in the intact animal model. Reg Anesth Pain Med 28:3-11. https://doi.org/10.1053/ rapm.2003.50014 
Grothendieck G, Kates L, Petzoldt T (2016) proto: prototype objectbased programming. R package version 1.0.0. https://CRAN.Rproject.org/package $=$ proto

Grunwald L-M, Stock R, Haag K et al (2019) Comparative characterization of human induced pluripotent stem cells (hiPSC) derived from patients with schizophrenia and autism. Transl Psychiatry 9:179. https://doi.org/10.1038/s41398-019-0517-3

Gu H, Wall SC, Rudnick G (1994) Stable expression of biogenic amine transporters reveals differences in inhibitor sensitivity, kinetics, and ion dependence. J Biol Chem 269:7124-7130

Gutbier S, May P, Berthelot S et al (2018) Major changes of cell function and toxicant sensitivity in cultured cells undergoing mild, quasi-natural genetic drift. Arch Toxicol 92:3487-3503. https:// doi.org/10.1007/s00204-018-2326-5

Han DD, Gu HH (2006) Comparison of the monoamine transporters from human and mouse in their sensitivities to psychostimulant drugs. BMC Pharmacol 6:6. https://doi. org/10.1186/1471-2210-6-6

Handel AE, Chintawar S, Lalic T et al (2016) Assessing similarity to primary tissue and cortical layer identity in induced pluripotent stem cell-derived cortical neurons through single-cell transcriptomics. Hum Mol Genet 25:989-1000. https://doi.org/10.1093/ hmg/ddv637

Hansson O, Castilho RF, Kaminski Schierle GS et al (2000) Additive effects of caspase inhibitor and lazaroid on the survival of transplanted rat and human embryonic dopamine neurons. Exp Neurol 164:102-111. https://doi.org/10.1006/exnr.2000.7406

Harris JE, Baldessarini RJ (1973) The uptake of [3H]dopamine by homogenates of rat corpus striatum: effects of cations. Life Sci 13:303-312. https://doi.org/10.1016/0024-3205(73)90221-X

Harris G, Hogberg H, Hartung T, Smirnova L (2017) 3D differentiation of LUHMES cell line to study recovery and delayed neurotoxic effects. Curr Protoc Toxicol 73:11.23.1-11.23.28. https://doi. org/10.1002/cptx.29

He M-L, Zemkova H, Koshimizu T et al (2003) Intracellular calcium measurements as a method in studies on activity of purinergic P2X receptor channels. Am J Physiol Cell Physiol 285:C467C479. https://doi.org/10.1152/ajpcell.00042.2003

He X, Liu Y-L, Conklin A et al (2016) Toxic cyanobacteria and drinking water: impacts, detection, and treatment. Harmful Algae 54:174-193. https://doi.org/10.1016/j.hal.2016.01.001

Hefft S, Kraushaar U, Geiger JRP, Jonas P (2002) Presynaptic shortterm depression is maintained during regulation of transmitter release at a GABAergic synapse in rat hippocampus. J Physiol 539:201-208. https://doi.org/10.1113/jphysiol.2001.013455

Helton TD, Xu W, Lipscombe D (2005) Neuronal L-type calcium channels open quickly and are inhibited slowly. J Neurosci 25:1024710251. https://doi.org/10.1523/JNEUROSCI.1089-05.2005

Hogberg HT, Sobanski T, Novellino A et al (2011) Application of micro-electrode arrays (MEAs) as an emerging technology for developmental neurotoxicity: evaluation of domoic acid-induced effects in primary cultures of rat cortical neurons. NeuroToxicology 32:158-168. https://doi.org/10.1016/j.neuro.2010.10.007

Hogg RC, Lewis RJ, Adams DJ (1998) Ciguatoxin (CTX-1) modulates single tetrodotoxin-sensitive sodium channels in rat parasympathetic neurones. Neurosci Lett 252:103-106. https://doi. org/10.1016/S0304-3940(98)00575-8

Hogg RC, Lewis RJ, Adams DJ (2002) Ciguatoxin-induced oscillations in membrane potential and action potential firing in rat parasympathetic neurons. Eur J Neurosci 16:242-248. https://doi.org/10. 1046/j.1460-9568.2002.02071.x

Hothorn T, Bretz F, Westfall P (2008) Simultaneous inference in general parametric models. Biom J 50:346-363. https://doi. org/10.1002/bimj.200810425

House JS, Grimm FA, Jima DD et al (2017) A pipeline for highthroughput concentration response modeling of gene expression for toxicogenomics. Front Genet 8:168. https://doi.org/10.3389/ fgene.2017.00168

Huang L, Keyser BM, Tagmose TM et al (2004) NNC 55-0396 [(1S,2S)-2-(2-( $N$-[(3-benzimidazol-2-yl)propyl]- $N$-methylamino) ethyl)-6-fluoro-1,2,3,4-tetrahydro-1-isopropyl-2-naphtyl cyclopropanecarboxylate dihydrochloride]: a new selective inhibitor of T-type calcium channels. J Pharmacol Exp Ther 309:193-199. https://doi.org/10.1124/jpet.103.060814

Huang C-J, Harootunian A, Maher MP et al (2006) Characterization of voltage-gated sodium-channel blockers by electrical stimulation and fluorescence detection of membrane potential. Nat Biotechnol 24:439-446. https://doi.org/10.1038/nbt1194

Huang C-Y, Liu C-L, Ting C-Y et al (2019) Human iPSC banking: barriers and opportunities. J Biomed Sci 26:87. https://doi. org/10.1186/s12929-019-0578-x

Huc S, Monteil A, Bidaud I et al (2009) Regulation of T-type calcium channels: signalling pathways and functional implications. Biochim Biophys Acta BBA Mol Cell Res 1793:947-952. https:// doi.org/10.1016/j.bbamcr.2008.11.003

Jones SR, Gainetdinov RR, Wightman RM, Caron MG (1998) Mechanisms of amphetamine action revealed in mice lacking the dopamine transporter. J Neurosci 18:1979-1986. https://doi. org/10.1523/JNEUROSCI.18-06-01979.1998

Kaneda M, Oyama Y, Ikemoto Y, Akaike N (1989) Blockade of the voltage-dependent sodium current in isolated rat hippocampal neurons by tetrodotoxin and lidocaine. Brain Res 484:348-351. https://doi.org/10.1016/0006-8993(89)90379-X

Karreman C, Klima S, Holzer A-K, Leist M (2020) CaFFEE: a program for evaluating time courses of $\mathrm{Ca}^{2+}$ dependent signal changes of complex cells loaded with fluorescent indicator dyes. Altern Anim Exp ALTEX 37:332-336. https://doi.org/10.14573 /altex.2003191

Kennedy PG (2013) Clinical features, diagnosis, and treatment of human African trypanosomiasis (sleeping sickness). Lancet Neurol 12:186-194. https://doi.org/10.1016/S1474-4422(12)70296 -X

Khakh BS, North RA (2012) Neuromodulation by extracellular ATP and P2X receptors in the CNS. Neuron 76:51-69. https://doi. org/10.1016/j.neuron.2012.09.024

Khakh BS, Burnstock G, Kennedy C et al (2001) International Union of Pharmacology. XXIV. Current status of the nomenclature and properties of P2X receptors and their subunits. Pharmacol Rev 53:107-118

Klima S, Suciu I, Hoelting L et al (2020) Examination of microcystin neurotoxicity using central and peripheral human neurons. ALTEX-Altern Anim Exp. https://doi.org/10.14573/altex.20031 82

Kondo T, Imamura K, Funayama M et al (2017) iPSC-Based compound screening and in vitro trials identify a synergistic anti-amyloid $\beta$ combination for Alzheimer's disease. Cell Rep 21:2304-2312. https://doi.org/10.1016/j.celrep.2017.10.109

Koshimizu T, Van Goor F, Tomić M et al (2000) Characterization of calcium signaling by purinergic receptor-channels expressed in excitable cells. Mol Pharmacol 58:936-945. https://doi. org $/ 10.1124 / \mathrm{mol} .58 .5 .936$

Kraushaar U, Jonas P (2000) Efficacy and stability of quantal GABA release at a hippocampal interneuron-principal neuron synapse. J Neurosci 20:5594-5607. https://doi.org/10.1523/JNEUR OSCI.20-15-05594.2000

Kraushaar U, Guenther E, Hess D (2017) Addressing functional neurotoxicity using the microelectrode array (MEA). In: Clements M, Roquemore L (eds) Stem cell-derived models in toxicology. Springer, New York, pp 293-309

Kreir M, Van Deuren B, Versweyveld S et al (2018) Do in vitro assays in rat primary neurons predict drug-induced seizure liability 
in humans? Toxicol Appl Pharmacol 346:45-57. https://doi. org/10.1016/j.taap.2018.03.028

Krueger BK (1990) Kinetics and block of dopamine uptake in synaptosomes from rat caudate nucleus. J Neurochem 55:260-267. https ://doi.org/10.1111/j.1471-4159.1990.tb08847.x

Krug AK, Balmer NV, Matt F et al (2013) Evaluation of a human neurite growth assay as specific screen for developmental neurotoxicants. Arch Toxicol 87:2215-2231. https://doi.org/10.1007/ s00204-013-1072-y

Krug AK, Gutbier S, Zhao L et al (2014) Transcriptional and metabolic adaptation of human neurons to the mitochondrial toxicant MPP +. Cell Death Dis 5:e1222-e1222. https://doi. org/10.1038/cddis.2014.166

Kuhar MJ, Zarbin MA (1978) Synaptosomal transport: a chloride dependence for choline, gaba, glycine and several other compounds. J Neurochem 31:251-256. https://doi. org/10.1111/j.1471-4159.1978.tb12456.x

Lee CH, Ruben PC (2008) Interaction between voltage-gated sodium channels and the neurotoxin, tetrodotoxin. Channels 2:407412. https://doi.org/10.4161/chan.2.6.7429

Leffler A, Reiprich A, Mohapatra DP, Nau C (2007) Use-dependent block by lidocaine but not amitriptyline is more pronounced in tetrodotoxin (TTX)-resistant $\mathrm{Na}_{\mathrm{V}} 1.8$ than in TTX-sensitive $\mathrm{Na}_{\mathrm{V}}$ channels. J Pharmacol Exp Ther 320:354-364. https://doi. org/10.1124/jpet.106.109025

Lehane L, Lewis RJ (2000) Ciguatera: recent advances but the risk remains. Int J Food Microbiol 61:91-125. https://doi. org/10.1016/S0168-1605(00)00382-2

Leist M, Hartung T (2013) Inflammatory findings on species extrapolations: humans are definitely no 70-kg mice. Arch Toxicol 87:563-567. https://doi.org/10.1007/s00204-013-1038-0

Lemon J (2006) Plotrix: a package in the red light district of R. R News 6:8-12

LePage KT, Goeger D, Yokokawa F et al (2005) The neurotoxic lipopeptide kalkitoxin interacts with voltage-sensitive sodium channels in cerebellar granule neurons. Toxicol Lett 158:133139. https://doi.org/10.1016/j.toxlet.2005.03.007

Lewis RJ, Sellin M, Poli MA et al (1991) Purification and characterization of ciguatoxins from moray eel (Lycodontis javanicus, Muraenidae). Toxicon 29:1115-1127. https://doi. org/10.1016/0041-0101(91)90209-A

Li M, Silberberg SD, Swartz KJ (2013) Subtype-specific control of P2X receptor channel signaling by ATP and $\mathrm{Mg}^{2+}$. Proc Natl Acad Sci 110:E3455-E3463. https://doi.org/10.1073/ pnas. 1308088110

Lieb A, Ortner N, Striessnig J (2014) C-terminal modulatory domain controls coupling of voltage-sensing to pore opening in Cav1.3 L-type $\mathrm{Ca}^{2+}$ channels. Biophys J 106:1467-1475. https://doi. org/10.1016/j.bpj.2014.02.017

Litaker RW, Vandersea MW, Faust MA et al (2010) Global distribution of ciguatera causing dinoflagellates in the genus $\mathrm{Gambi-}$ erdiscus. Toxicon 56:711-730. https://doi.org/10.1016/j.toxic on.2010.05.017

Litaker RW, Holland WC, Hardison DR et al (2017) Ciguatoxicity of Gambierdiscus and Fukuyoa species from the Caribbean and Gulf of Mexico. PLoS ONE 12:e0185776. https://doi. org/10.1371/journal.pone.0185776

Little D, Ketteler R, Gissen P, Devine MJ (2019) Using stem cellderived neurons in drug screening for neurological diseases. Neurobiol Aging 78:130-141. https://doi.org/10.1016/j.neuro biolaging.2019.02.008

Llewellyn LE (2009) Sodium channel inhibiting marine toxins. In: Fusetani N, Kem W (eds) Marine toxins as research tools. Springer, Berlin, pp 67-97

Lohren H, Blagojevic L, Fitkau R et al (2015) Toxicity of organic and inorganic mercury species in differentiated human neurons and human astrocytes. J Trace Elem Med Biol 32:200-208. https://doi.org/10.1016/j.jtemb.2015.06.008

Love MI, Huber W, Anders S (2014) Moderated estimation of fold change and dispersion for RNA-seq data with DESeq2. Genome Biol 15:550. https://doi.org/10.1186/s1305 9-014-0550-8

MacKintosh C, Beattie KA, Klumpp S et al (1990) Cyanobacterial microcystin-LR is a potent and specific inhibitor of protein phosphatases 1 and $2 \mathrm{~A}$ from both mammals and higher plants. FEBS Lett 264:187-192. https://doi.org/10.1016/00145793(90)80245-E

Mather L, Copeland S, Ladd L (2005) Acute toxicity of local anesthetics: underlying pharmacokinetic and pharmacodynamic concepts. Reg Anesth Pain Med 30:553-566. https://doi. org/10.1016/j.rapm.2005.07.186

Mattei C, Legros C (2014) The voltage-gated sodium channel: a major target of marine neurotoxins. Toxicon 91:84-95. https ://doi.org/10.1016/j.toxicon.2014.09.016

McConnell ER, McClain MA, Ross J et al (2012) Evaluation of multi-well microelectrode arrays for neurotoxicity screening using a chemical training set. NeuroToxicology 33:1048-1057. https://doi.org/10.1016/j.neuro.2012.05.001

McCormack K, Santos S, Chapman ML et al (2013) Voltage sensor interaction site for selective small molecule inhibitors of voltage-gated sodium channels. Proc Natl Acad Sci 110:E2724E2732. https://doi.org/10.1073/pnas.1220844110

McKernan R, Watt FM (2013) What is the point of large-scale collections of human induced pluripotent stem cells? Nat Biotechnol 31:875-877. https://doi.org/10.1038/nbt.2710

McNaughton R, Huet G, Shakir S (2014) An investigation into drug products withdrawn from the EU market between 2002 and 2011 for safety reasons and the evidence used to support the decision-making. BMJ Open 4:e004221. https://doi. org/10.1136/bmjopen-2013-004221

Mead AN, Amouzadeh HR, Chapman K et al (2016) Assessing the predictive value of the rodent neurofunctional assessment for commonly reported adverse events in phase I clinical trials. Regul Toxicol Pharmacol 80:348-357. https://doi. org/10.1016/j.yrtph.2016.05.002

Millard DC, Nicolini AM, Arrowood CA et al (2019) Evaluating the use of microelectrode array technology and cell-based neuronal culture models for proconvulsant risk assessment: progress from the HESI NeuTox consortium. J Pharmacol Toxicol Methods 99:106595. https://doi.org/10.1016/j.vasen .2019.05.076

Mohammed ZA, Doran C, Grundy D, Nassar MA (2017) Veratridine produces distinct calcium response profiles in mouse dorsal root ganglia neurons. Sci Rep 7:45221. https://doi.org/10.1038/srep4 5221

Molgó J, Shimahara T, Legrand AM (1993) Ciguatoxin, extracted from poisonous morays eels, causes sodium-dependent calcium mobilization in NG108-15 neuroblastoma $\times$ glioma hybrid cells. Neurosci Lett 158:147-150. https://doi.org/10.1016/03043940(93)90250-O

Neal JM, Bernards CM, Butterworth JF et al (2010) ASRA practice advisory on local anesthetic systemic toxicity. Reg Anesth Pain Med 35:152-161. https://doi.org/10.1097/AAP.0b013e3181 d22fcd

Nicholson GM, Lewis RJ (2006) Ciguatoxins: cyclic polyether modulators of voltage-gated iion channel function. Mar Drugs 4:82-118. https://doi.org/10.3390/md403082

Nicolas J, Hendriksen PJM, van Kleef RGDM et al (2014) Detection of marine neurotoxins in food safety testing using a multielectrode array. Mol Nutr Food Res 58:2369-2378. https://doi.org/10.1002/ mnfr.201400479 
Noda M, Suzuki H, Numa S, Stühmer W (1989) A single point mutation confers tetrodotoxin and saxitoxin insensitivity on the sodium channel II. FEBS Lett 259:213-216. https://doi. org/10.1016/0014-5793(89)81531-5

North RA (2002) Molecular physiology of P2X receptors. Physiol Rev 82:1013-1067. https://doi.org/10.1152/physrev.00015.2002

Odawara A, Katoh H, Matsuda N, Suzuki I (2016) Physiological maturation and drug responses of human induced pluripotent stem cell-derived cortical neuronal networks in long-term culture. Sci Rep 6:26181. https://doi.org/10.1038/srep26181

Odawara A, Matsuda N, Ishibashi Y et al (2018) Toxicological evaluation of convulsant and anticonvulsant drugs in human induced pluripotent stem cell-derived cortical neuronal networks using an MEA system. Sci Rep 8:10416. https://doi.org/10.1038/s4159 8-018-28835-7

Ogata N, Ohishi Y (2002) Molecular diversity of structure and function of the voltage-gated $\mathrm{Na}^{+}$channels. Jpn J Pharmacol 88:365-377. https://doi.org/10.1254/jjp.88.365

Oliva MK, McGarr TC, Beyer BJ et al (2014) Physiological and genetic analysis of multiple sodium channel variants in a model of genetic absence epilepsy. Neurobiol Dis 67:180-190. https:// doi.org/10.1016/j.nbd.2014.03.007

Olson H, Betton G, Robinson D et al (2000) Concordance of the toxicity of pharmaceuticals in humans and in animals. Regul Toxicol Pharmacol 32:56-67. https://doi.org/10.1006/rtph.2000.1399

Onakpoya IJ, Heneghan CJ, Aronson JK (2016) Post-marketing withdrawal of 462 medicinal products because of adverse drug reactions: a systematic review of the world literature. BMC Med 14:10. https://doi.org/10.1186/s12916-016-0553-2

Ooms J (2020) magick: advanced graphics and image-processing in R. R package version 2.3. https://CRAN.R-project.org/packa ge $=$ magick

Palmer RK, Boyer JL, Schachter JB et al (1998) Agonist action of adenosine triphosphates at the human P2Y1 receptor. Mol Pharmacol 54:1118-1123. https://doi.org/10.1124/mol.54.6.1118

Patel RR, Barbosa C, Brustovetsky T et al (2016) Aberrant epilepsyassociated mutant $\mathrm{Na}_{\mathrm{V}} 1.6$ sodium channel activity can be targeted with cannabidiol. Brain 139:2164-2181. https://doi. org/10.1093/brain/aww129

Hamblin PA, ElspethM McLachlan, Lewis RJ (1995) Sub-nanomolar concentrations of ciguatoxin-1 excite preganglionic terminals in guinea pig sympathetic ganglia. Naunyn Schmiedebergs Arch Pharmacol 352:236-246. https://doi.org/10.1007/BF00176780

Pei Y, Peng J, Behl M et al (2016) Comparative neurotoxicity screening in human iPSC-derived neural stem cells, neurons and astrocytes. Brain Res 1638:57-73. https://doi.org/10.1016/j.brain res.2015.07.048

Pottel J, Armstrong D, Zou L et al (2020) The activities of drug inactive ingredients on biological targets. Science 369:403-413. https:// doi.org/10.1126/science.aaz9906

Power KE, Carlin KP, Fedirchuk B (2012) Modulation of voltage-gated sodium channels hyperpolarizes the voltage threshold for activation in spinal motoneurones. Exp Brain Res 217:311-322. https ://doi.org/10.1007/s00221-011-2994-3

Puchałowicz K, Tarnowski M, Baranowska-Bosiacka I et al (2014) P2X and $\mathrm{P} 2 \mathrm{Y}$ receptors - role in the pathophysiology of the nervous system. Int J Mol Sci 15:23672-23704. https://doi.org/10.3390/ ijms 151223672

Qi A-D, Kennedy C, Harden TK, Nicholas RA (2001) Differential coupling of the human P2Y11 receptor to phospholipase $\mathrm{C}$ and adenylyl cyclase. Br J Pharmacol 132:318-326. https://doi. org/10.1038/sj.bjp.0703788

R Core Team (2020) R: a language and environment for statistical computing. R Foundation for Statistical Computing, Vienna, Austria. https://www.R-project.org
Randrup A, Bræstrup C (1977) Uptake inhibition of biogenic amines by newer antidepressant drugs: relevance to the dopamine hypothesis of depression. Psychopharmacology 53:309-314. https://doi. org/10.1007/BF00492370

Redfern W, Ewart L, Hammond T et al (2010) Impact and frequency of different toxicities throughout the pharmaceutical life cycle. Toxicologist 114:1081

Riquelme J, Wellmann M, Sotomayor-Zárate R, Bonansco C (2020) Gliotransmission: a novel target for the development of antiseizure drugs. Neuroscientist. https://doi.org/10.1177/1073858420 901474

Ritz C, Baty F, Streibig JC, Gerhard D (2015) Dose-response analysis using R. PLoS ONE 10:e0146021. https://doi.org/10.1371/ journal.pone.0146021

Robertson SD, Matthies HJG, Galli A (2009) A closer look at amphetamine-induced reverse transport and trafficking of the dopamine and norepinephrine transporters. Mol Neurobiol 39:73-80. https://doi.org/10.1007/s12035-009-8053-4

Rothman RB, Lewis B, Dersch C et al (1993) Identification of a GBR12935 homolog, LR1111, which is over 4,000-fold selective for the dopamine transporter, relative to serotonin and norepinephrine transporters. Synapse 14:34-39. https://doi. org/10.1002/syn.890140106

Ryan KR, Sirenko O, Parham F et al (2016) Neurite outgrowth in human induced pluripotent stem cell-derived neurons as a high-throughput screen for developmental neurotoxicity or neurotoxicity. NeuroToxicology 53:271-281. https://doi. org/10.1016/j.neuro.2016.02.003

Sandström J, Broyer A, Zoia D et al (2017) Potential mechanisms of development-dependent adverse effects of the herbicide paraquat in 3D rat brain cell cultures. NeuroToxicology 60:116124. https://doi.org/10.1016/j.neuro.2017.04.010

Schenk JO (2002) The functioning neuronal transporter for dopamine: kinetic mechanisms and effects of amphetamines, cocaine and methylphenidate. Prog Drug Res Fortschritte Arzneimittelforschung Progres Rech Pharm 59:111-131. https:// doi.org/10.1007/978-3-0348-8171-5_4

Schildknecht S, Karreman C, Pöltl D et al (2013) Generation of genetically-modified human differentiated cells for toxicological tests and the study of neurodegenerative diseases. ALTEX Altern Anim Exp 30:427-444. https://doi.org/10.14573/altex .2013.4.427

Schmidt BZ, Lehmann M, Gutbier S et al (2017) In vitro acute and developmental neurotoxicity screening: an overview of cellular platforms and high-throughput technical possibilities. Arch Toxicol 91:1-33. https://doi.org/10.1007/s00204-016-1805-9

Schmitt KC, Rothman RB, Reith MEA (2013) Nonclassical pharmacology of the dopamine transporter: atypical inhibitors, allosteric modulators, and partial substrates. J Pharmacol Exp Ther 346:2-10. https://doi.org/10.1124/jpet.111.191056

Scholz D, Pöltl D, Genewsky A et al (2011) Rapid, complete and large-scale generation of post-mitotic neurons from the human LUHMES cell line. J Neurochem 119:957-971. https://doi.org /10.1111/j.1471-4159.2011.07255.x

Schultz L, Zurich M-G, Culot M et al (2015) Evaluation of druginduced neurotoxicity based on metabolomics, proteomics and electrical activity measurements in complementary CNS in vitro models. Toxicol In Vitro 30:138-165. https://doi. org/10.1016/j.tiv.2015.05.016

Sherman SP, Bang AG (2018) High-throughput screen for compounds that modulate neurite growth of human induced pluripotent stem cell-derived neurons. Dis Model Mech. https://doi. org/10.1242/dmm.031906

Siciliano CA, Calipari ES, Jones SR (2014) Amphetamine potency varies with dopamine uptake rate across striatal subregions. J Neurochem 131:348-355. https://doi.org/10.1111/jnc.12808 
Sirenko O, Parham F, Dea S et al (2019) Functional and mechanistic neurotoxicity profiling using human iPSC-derived neural 3D cultures. Toxicol Sci 167:58-76. https://doi.org/10.1093/toxsc i/kfy 218

Sitte HH, Huck S, Reither H et al (1998) Carrier-mediated release, transport rates, and charge transfer induced by amphetamine, tyramine, and dopamine in mammalian cells transfected with the human dopamine transporter. J Neurochem 71:1289-1297. https://doi.org/10.1046/j.1471-4159.1998.71031289.x

Sivonen K, Jones G (1999) Cyanobacterial toxins. In: Chorus I, Bartram J (eds) Toxic cyanobacteria in water: a guide to their public health consequences, monitoring and management. E\&FN Spon, pp 41-111

Skinner MP, Brewer TD, Johnstone R et al (2011) Ciguatera fish poisoning in the Pacific Islands (1998 to 2008). PLoS Negl Trop Dis 5:e1416. https://doi.org/10.1371/journal.pntd.0001416

Smirnova L, Harris G, Delp J et al (2016) A LUHMES 3D dopaminergic neuronal model for neurotoxicity testing allowing longterm exposure and cellular resilience analysis. Arch Toxicol 90:2725-2743. https://doi.org/10.1007/s00204-015-1637-z

Sonawane KB, Cheng N, Hansen RA (2018) Serious adverse drug events reported to the FDA: analysis of the FDA adverse event reporting system 2006-2014 database. J Manag Care Spec Pharm 24:682-690. https://doi.org/10.18553/ jmcp.2018.24.7.682

Sonders MS, Zhu S-J, Zahniser NR et al (1997) Multiple ionic conductances of the human dopamine transporter: the actions of dopamine and psychostimulants. J Neurosci 17:960-974. https ://doi.org/10.1523/JNEUROSCI.17-03-00960.1997

Stiegler NV, Krug AK, Matt F, Leist M (2011) Assessment of chemical-induced impairment of human neurite outgrowth by multiparametric live cell imaging in high-density cultures. Toxicol Sci 121:73-87. https://doi.org/10.1093/toxsci/kfr034

Sulzer D, Chen T, Lau Y et al (1995) Amphetamine redistributes dopamine from synaptic vesicles to the cytosol and promotes reverse transport. J Neurosci 15:4102-4108. https://doi.org/10.1523/ JNEUROSCI.15-05-04102.1995

Syed N-H, Kennedy C (2012) Pharmacology of P2X receptors. Wiley Interdiscip Rev Membr Transp Signal 1:16-30. https://doi. org/10.1002/wmts.1

Terlau H, Heinemann SH, Stühmer W et al (1991) Mapping the site of block by tetrodotoxin and saxitoxin of sodium channel II. FEBS Lett 293:93-96. https://doi.org/10.1016/0014-5793(91)81159-6

Tong Z-B, Hogberg H, Kuo D et al (2017) Characterization of three human cell line models for high-throughput neuronal cytotoxicity screening: neurotoxicity models. J Appl Toxicol 37:167-180. https://doi.org/10.1002/jat.3334

Tóth A, Antal Z, Bereczki D, Sperlágh B (2019) Purinergic signalling in Parkinson's disease: a multi-target system to combat neurodegeneration. Neurochem Res 44:2413-2422. https://doi. org/10.1007/s11064-019-02798-1

Trestle Technology, LLC (2017) shinyTree: jsTree bindings for shiny. $\mathrm{R}$ package version 0.2 .5

Tsukamoto T, Chiba Y, Nakazaki A et al (2017) Inhibition of veratridine-induced delayed inactivation of the voltage-sensitive sodium channel by synthetic analogs of crambescin B. Bioorg Med Chem Lett 27:1247-1251. https://doi.org/10.1016/j.bmcl.2017.01.054

Tukker AM, Wijnolts FMJ, de Groot A, Westerink RHS (2018) Human iPSC-derived neuronal models for in vitro neurotoxicity assessment. NeuroToxicology 67:215-225. https://doi.org/10.1016/j. neuro.2018.06.007

Tukker AM, van Kleef RGDM, Wijnolts FMJ et al (2020) Towards animalfree neurotoxicity screening: applicability of hiPSC-derived neuronal models for in vitro seizure liability assessment. ALTEX Altern Anim Exp 37:121-135. https://doi.org/10.14573/altex.1907121
Ulbricht W (1998) Effects of veratridine on sodium currents and fluxes. Reviews of physiology biochemistry and pharmacology, vol 133. Springer, Berlin, pp 1-54

Vaidyanathan R, Xie Y, Allaire J et al (2019) htmlwidgets: HTML widgets for R. R package version 1.5.1. https://CRAN.R-proje ct.org/package $=$ htmlwidgets

Vassallo A, Chiappalone M, De Camargos LR et al (2016) A multilaboratory evaluation of microelectrode array-based measurements of neural network activity for acute neurotoxicity testing. NeuroToxicology. https://doi.org/10.1016/j.neuro.2016.03.019

Vetter I, Mozar CA, Durek T et al (2012) Characterisation of Nav types endogenously expressed in human SH-SY5Y neuroblastoma cells. Biochem Pharmacol 83:1562-1571. https://doi. org/10.1016/j.bcp.2012.02.022

Vilariño N, Louzao MC, Abal P et al (2018) Human poisoning from marine toxins: unknowns for optimal consumer protection. Toxins 10:324. https://doi.org/10.3390/toxins 10080324

Virginio C, Robertson G, Surprenant A, North RA (1998) Trinitrophenyl-substituted nucleotides are potent antagonists selective for $\mathrm{P} 2 \mathrm{X} 1, \mathrm{P} 2 \mathrm{X} 3$, and heteromeric $\mathrm{P} 2 \mathrm{X} 2 / 3$ receptors. Mol Pharmacol 53:969-973

Volpato V, Webber C (2020) Addressing variability in iPSC-derived models of human disease: guidelines to promote reproducibility. Dis Model Mech 13:dmm042317. https://doi.org/10.1242/ dmm.042317

Volpato V, Smith J, Sandor C et al (2018) Reproducibility of molecular phenotypes after long-term differentiation to human iPSCderived neurons: a multi-site omics study. Stem Cell Rep 11:897911. https://doi.org/10.1016/j.stemcr.2018.08.013

von Kügelgen I, Harden TK (2011) Molecular pharmacology, physiology, and structure of the $\mathrm{P} 2 \mathrm{Y}$ receptors. Advances in pharmacology. Elsevier, Amsterdam, pp 373-415

Wagner GP, Kin K, Lynch VJ (2012) Measurement of mRNA abundance using RNA-seq data: RPKM measure is inconsistent among samples. Theory Biosci 131:281-285. https://doi. org/10.1007/s12064-012-0162-3

Waldo GL, Harden TK (2004) Agonist binding and Gq-stimulating activities of the purified human $\mathrm{P}_{2} \mathrm{Y}_{1}$ receptor. Mol Pharmacol 65:426-436. https://doi.org/10.1124/mol.65.2.426

Walker AL, Imam SZ, Roberts RA (2018) Drug discovery and development: biomarkers of neurotoxicity and neurodegeneration. Exp Biol Med 243:1037-1045. https://doi.org/10.1177/1535370218 801309

Wang S-Y, Wang GK (2003) Voltage-gated sodium channels as primary targets of diverse lipid-soluble neurotoxins. Cell Signal 15:151-159. https://doi.org/10.1016/S0898-6568(02)00085-2

Wang Y, Mi J, Lu K et al (2015) Comparison of Gating properties and use-dependent block of $\mathrm{Na}_{\mathrm{V}} 1.5$ and $\mathrm{Na}_{\mathrm{V}} 1.7$ channels by antiarrhythmics mexiletine and lidocaine. PLoS ONE 10:e0128653. https://doi.org/10.1371/journal.pone.0128653

Wéry M (1994) Drug used in the treatment of sleeping sickness (human African trypanosomiasis: HAT). Int J Antimicrob Agents 4:227238. https://doi.org/10.1016/0924-8579(94)90012-4

Westrick JA, Szlag DC, Southwell BJ, Sinclair J (2010) A review of cyanobacteria and cyanotoxins removal/inactivation in drinking water treatment. Anal Bioanal Chem 397:1705-1714. https://doi. org/10.1007/s00216-010-3709-5

White PJ, Webb TE, Boarder MR (2003) Characterization of a $\mathrm{Ca}^{2+}$ response to both UTP and ATP at human P2Y11 receptors: evidence for agonist-specific signaling. Mol Pharmacol 63:13561363. https://doi.org/10.1124/mol.63.6.1356

Wickham H (2016) ggplot2: elegant graphics for data analysis. Springer, Berlin

Wickham H (2020) modelr: modelling functions that work with the pipe. R package version 0.1.6. https://CRAN.R-project.org/packa ge $=$ modelr 
Wickham H, Averick M, Bryan J et al (2019) Welcome to the Tidyverse. J Open Source Softw 4:1686. https://doi.org/10.21105 /joss.01686

Wickham H, François R, Henry L, Müller K (2020) dplyr: a grammar of data manipulation. $\mathrm{R}$ package version 0.8.5. https://CRAN.Rproject.org/package $=$ dplyr

Wiese M, D'Agostino PM, Mihali TK et al (2010) Neurotoxic alkaloids: saxitoxin and its analogs. Mar Drugs 8:2185-2211. https ://doi.org/10.3390/md8072185

Wilke CO (2019) cowplot: streamlined plot theme and plot annotations for "ggplot2". R package version 1.0.0. https://CRAN.R-proje ct.org/package $=$ cowplot

Wilson MS, Graham JR, Ball AJ (2014) Multiparametric high content analysis for assessment of neurotoxicity in differentiated neuronal cell lines and human embryonic stem cell-derived neurons. NeuroToxicology 42:33-48. https://doi.org/10.1016/j.neuro .2014 .03 .013

Witt B, Meyer S, Ebert F et al (2017) Toxicity of two classes of arsenolipids and their water-soluble metabolites in human differentiated neurons. Arch Toxicol 91:3121-3134. https://doi.org/10.1007/ s00204-017-1933-x

Xia N, Zhang P, Fang F et al (2016) Transcriptional comparison of human induced and primary midbrain dopaminergic neurons. Sci Rep 6:20270. https://doi.org/10.1038/srep20270
Xu X, Lei Y, Luo J et al (2013) Prevention of $\beta$-amyloid induced toxicity in human iPS cell-derived neurons by inhibition of cyclindependent kinases and associated cell cycle events. Stem Cell Res 10:213-227. https://doi.org/10.1016/j.scr.2012.11.005

Young MD, Wakefield MJ, Smyth GK, Oshlack A (2010) Gene ontology analysis for RNA-seq: accounting for selection bias. Genome Biol 11:R14. https://doi.org/10.1186/gb-2010-11-2-r14

Zhang Z, Zhao Z, Liu Y et al (2013) Kinetic model of $\mathrm{Na}_{\mathrm{V}} 1.5$ channel provides a subtle insight into slow inactivation associated excitability in cardiac cells. PLoS ONE 8:e64286. https://doi. org/10.1371/journal.pone.0064286

Zhang X, Yin M, Zhang M (2014) Cell-based assays for Parkinson's disease using differentiated human LUHMES cells. Acta Pharmacol Sin 35:945-956. https://doi.org/10.1038/aps.2014.36

Zhang X, Bi R, Zhang P, Gan Y (2018) Veratridine modifies the gating of human voltage-gated sodium channel $\mathrm{Na}_{\mathrm{V}} 1.7$. Acta Pharmacol Sin 39:1716-1724. https://doi.org/10.1038/s41401-018-0065-Z

Publisher's Note Springer Nature remains neutral with regard to jurisdictional claims in published maps and institutional affiliations. 